\title{
WestVirginiaUniversity
}

THE RESEARCH REPOSITORY @ WVU

Graduate Theses, Dissertations, and Problem Reports

2004

\section{Characteristics of West Virginia secondary agricultural educators}

James C. Beatty

West Virginia University

Follow this and additional works at: https://researchrepository.wvu.edu/etd

\section{Recommended Citation}

Beatty, James C., "Characteristics of West Virginia secondary agricultural educators" (2004). Graduate Theses, Dissertations, and Problem Reports. 2024.

https://researchrepository.wvu.edu/etd/2024

This Thesis is protected by copyright and/or related rights. It has been brought to you by the The Research Repository @ WVU with permission from the rights-holder(s). You are free to use this Thesis in any way that is permitted by the copyright and related rights legislation that applies to your use. For other uses you must obtain permission from the rights-holder(s) directly, unless additional rights are indicated by a Creative Commons license in the record and/ or on the work itself. This Thesis has been accepted for inclusion in WVU Graduate Theses, Dissertations, and Problem Reports collection by an authorized administrator of The Research Repository @ WVU. For more information, please contact researchrepository@mail.wvu.edu. 
Characteristics of West Virginia Secondary Agricultural Educators

James C. Beatty

Thesis submitted to the

Davis College of Agriculture, Forestry, and Consumer Sciences

at West Virginia University

in partial fulfillment of the requirements

for the degree of

Master of Science

in

Agricultural and Environmental Education

Harry N. Boone, Jr., Ph.D., Chair

Stacy A. Gartin, Ph.D.

Deborah A. Boone, Ph.D.

Division of Resource Management

Morgantown, West Virginia

2004

Keywords: Agriculture Education, Teacher Evaluation, Effective Teacher, Teacher Characteristics 


\author{
ABSTRACT \\ Characteristics of West Virginia Secondary Agricultural Educators \\ James Christopher Beatty
}

All agricultural educators are expected to teach each student the three aspects of the agricultural education program, FFA, Supervised Agricultural Experience programs, and classroom and laboratory instruction. The purpose of this study was to determine the characteristics of an agricultural educator in the state of West Virginia. Agricultural educators rated reading, writing, and mathematics incorporation into the curriculum above average in the survey. They also felt that they encouraged professional and respectful relationships with their students almost all of the time. The amount of sarcasm used in the classroom, and bypassing school policy when the situation warranted it, returned varying results that should be studied more intensely in the future. Agricultural educators, based on the results of this instrument, need to become more involved in professional organizations in order to keep themselves truly abreast of new developments within their profession. 


\section{DEDICATION}

This thesis is dedicated to my wife Kelle and two children, Krystopher and Kelseigh, who have always been supportive of my educational goals. You have kept me going through the tough times and long hours that have been spent completing this thesis. Thank you for your unconditional support and love as I complete my requirements for my graduate degree. 


\section{ACKNOWLEDGEMENTS}

I would like to express sincere thanks to my graduate advisor, Dr. Harry N. Boone, for the constant support and encouragement that was provided to me during my graduate studies. Dr. Boone always had time to spend answering questions and guiding me in the direction I should go in completing my graduate degree. Dr. Boone would communicate with me almost daily at some points during the writing of this document to ensure I completed it in a timely manner. Without his constant encouragement and guidance it would have taken me a substantially longer time to complete the requirements for my Master’s Degree.

A special thanks is given to the members of my committee that included; Dr. Stacy A. Gartin, and Dr. Deborah A. Boone. Without their willingness to help and participate on my committee the attainment of my degree would not have been possible.

Thank you to Mrs. Alice Compton who assisted with copying the documents and helping to ensure that they were mailed. She also was always available to help with anything that was necessary.

An enormous thank you goes to my parents, Rick and Eileen Beatty. They have always supported me in every aspect of my life. Thank you for encouraging me to continue when the times were rough. Without your support I would not be where I am today.

A final thank you goes to the agriculture educators in the state of West Virginia who took the time to complete the survey that provided the data included. Without their dedication to the advancement of the agriculture education profession, they would not be able to continually exceed the expectations set upon them. 


\section{TABLE OF CONTENTS}

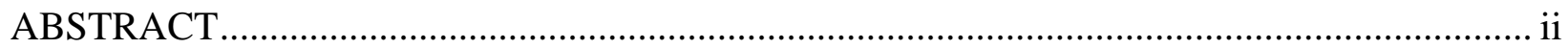

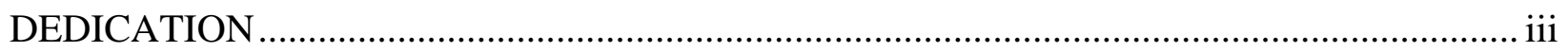

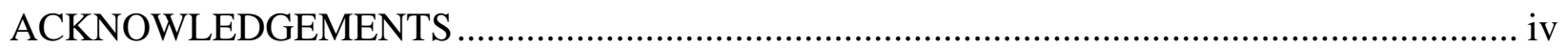

LIST OF TABLES ............................................................................................... viii

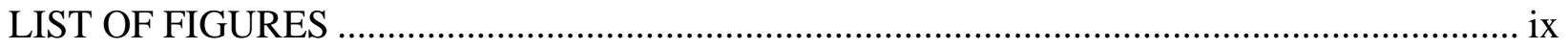

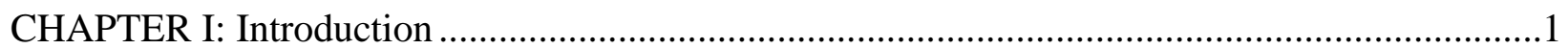

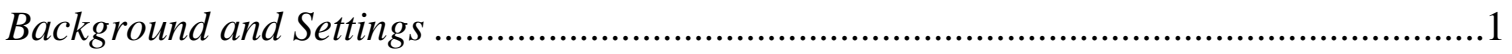

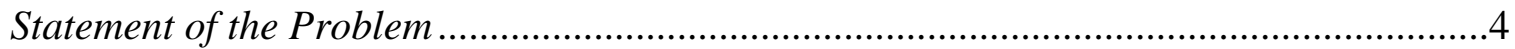

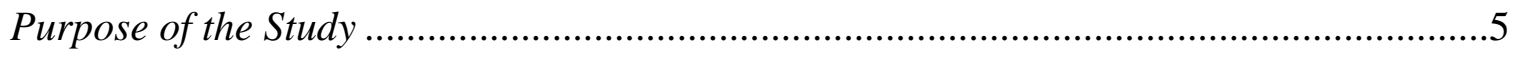

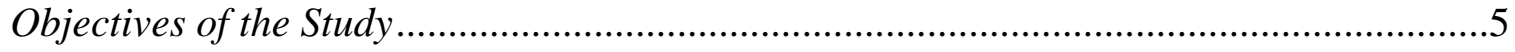

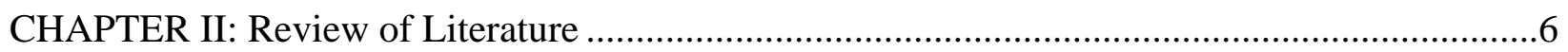

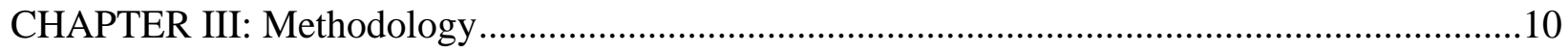

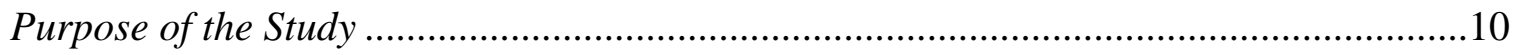

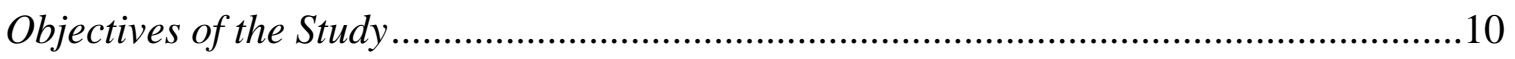

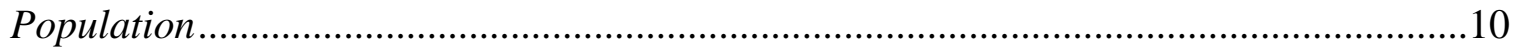

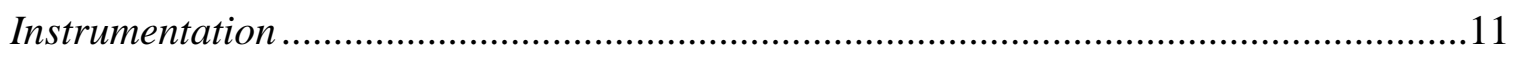

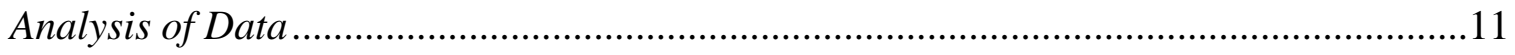

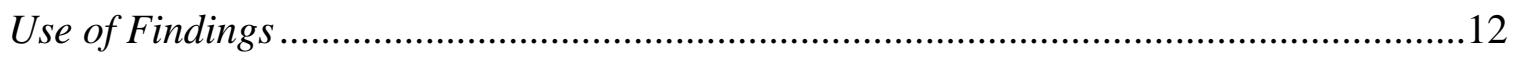

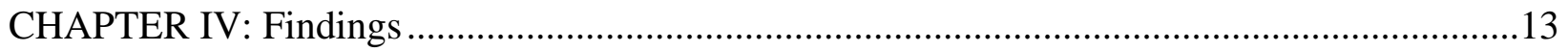

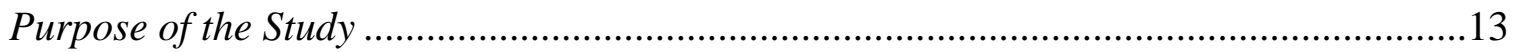

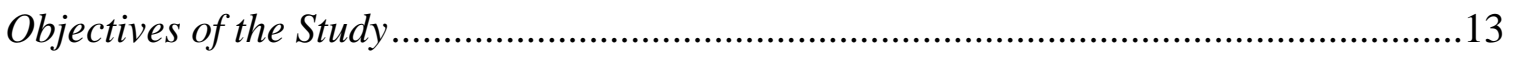

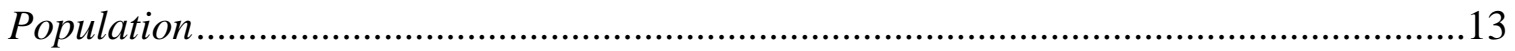




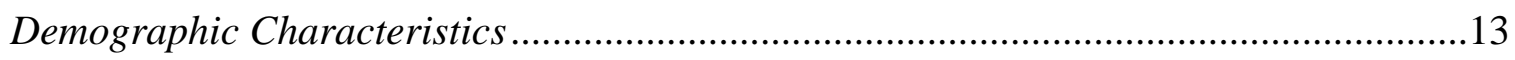

Years of Teaching Experience ………………………….........................................14

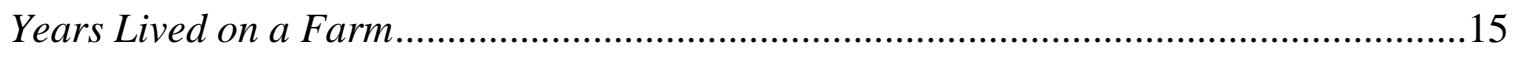

Years Lived in Current School District.....................................................................16

Number of Students with a Supervised Agriculture Experience Program..........................17

Percentage of Students Who Were FFA Members..........................................................18

Number of Professional Organizations ......................................................................19

Characteristics of West Virginia Agriculture Teachers...................................................23

Organized Structures and Class Management …………..............................................26

Professional Responsibilities .....................................................................................30

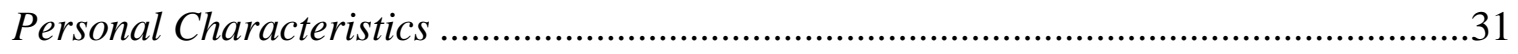

CHAPTER V: Summary, Conclusions, and Recommendations ………………………................36

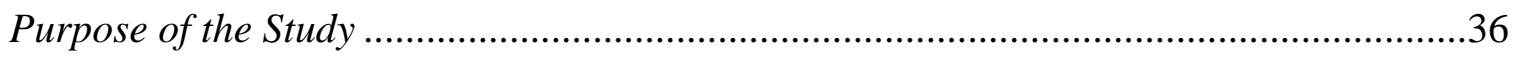

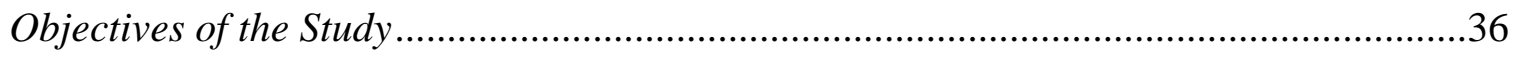

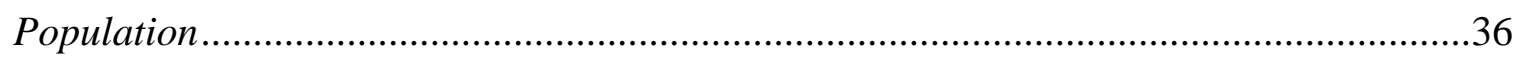

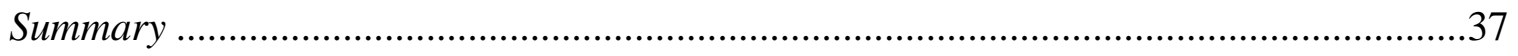

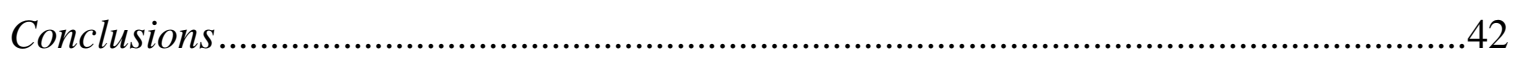

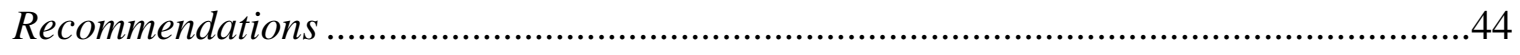

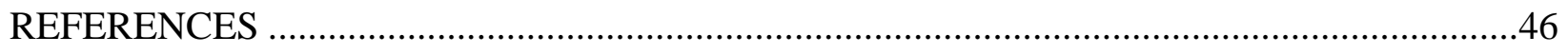

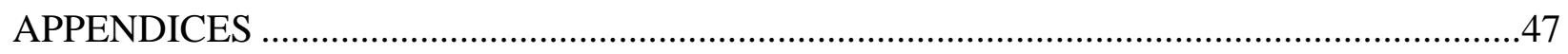

APPENDIX A: Cover Letter ………………………..................................................

APPENDIX B: Follow-Up Cover Letter …………………........................................50

APPENDIX C: Questionnaire.........................................................................................52 


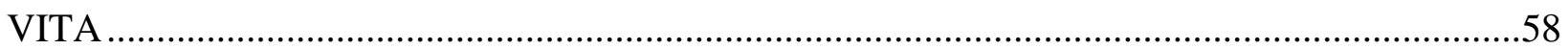




\section{LIST OF TABLES}

Table Title Page

$1 \quad$ Professional Agricultural Organization Membership or Non-membership ..........22

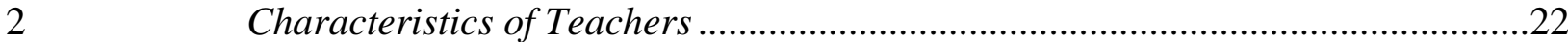

$3 \quad$ Characteristics of West Virginia Agricultural Educators ...................................32 


\section{LIST OF FIGURES}

Figure Title Page

1 Distribution of Respondents by Age Group................................................14

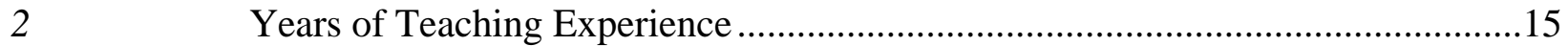

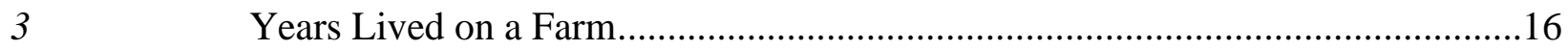

$4 \quad$ Years Living in Current School District .....................................................17

5 Percentage of Students having Supervised Agricultural Experience Program ......18

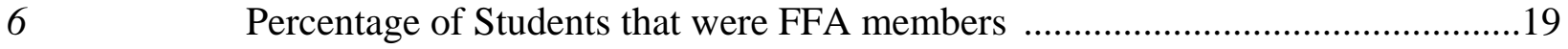

$7 \quad$ Professional Agricultural Organization Memberships......................................20

8 Membership in Professional Agricultural Organizations Yes or No ....................21

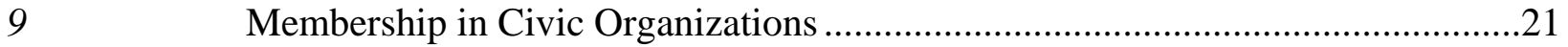




\section{CHAPTER I}

Introduction

\section{Background and Setting:}

“Agriculture education may be defined as systematic instruction in agriculture at the elementary, secondary, postsecondary, or adult level for the purpose of preparing persons for initial entry or reentry into occupations in agriculture” (Phipps \& Osborne, 1988, p. 3). This statement has held true since the beginning of public education. The first classes of agriculture education “were academic non-vocational courses” (Phipps \& Osborne, 1988, p. 3). Before the passage of the Smith Hughes Act in 1917 that provided funds to promote vocational education in agriculture for present and prospective farmers, thirty states were teaching agriculture courses. Agriculture is rooted in American history because we have always depended on production farming for sustenance. "Passage of the Smith-Hughes Act in 1917 suddenly fostered a great interest in agricultural education” (Hillison, 1997, p. 2). Since the Smith Hughes Act of 1917, the objective of agriculture education has changed from livestock and crop production, to promoting more diverse opportunities throughout agriculture that may or may not include production agriculture. So what makes an agriculture education class different from other educational programs?

Agriculture students are exposed to three different aspects of the agriculture education curriculum in every course they take. These three aspects are education in the classroom and laboratory, leadership development through the FFA, and supervised agriculture experience (SAE) programs (National FFA Organization, 2000; Hughes \& Barrick, 1991). “One part of agriculture education is the classroom, greenhouse, agriculture mechanics shop, or other laboratories. Some of the time spent in the agriculture classroom will be similar to other 
education classes...other times the class will be more hands-on and tied to the real world" (National FFA Organization, 2000, p. 6). "FFA is the organization for students in agriculture" (National FFA Organization, 2000, p. 6). "In the FFA students practice what they are learning in real life situations. Supervised agriculture experience programs are hands-on agriculture programs that the student creates and carries out” (National FFA Organization, 2000, p. 6; Hughes \& Barrick, 1991). One emphasis in recruiting students to an agriculture education program is the fact that they will be exposed to real life situations in all aspects of the classroom, FFA, and SAE programs. This is very attractive to students because they look for opportunities in high school to get out of their seats and learn something that may not be in a textbook. This is only the beginning of what an agriculture educator offers students that other programs can not. If agriculture education is different from academic classrooms, why are they evaluated on the same objectives as an academic or vocational education teacher? Students are exposed to the three different aspects of agriculture education while enrolled in classes. Should agriculture educators be evaluated with just a standard evaluation form or should there be an alternate assessment to determine the extent to which the agriculture educator is implementing the total agriculture program.

Why is evaluation necessary?-It is important to evaluate the total agricultural education program in order to:

1. Find out the strengths and weaknesses of the program,

2. Help to evaluate the effectiveness of individual teacher's activities, and

3. Determine ways and means of improving the program. (Phipps \& Osborne, 1988, p. 297) 
The West Virginia Department of Education sets forth standards of evaluation in the secondary classroom in Policy 5310. In section 126-142-9, In Evaluation Criteria for Classroom Teachers, it states:

Classroom teachers who are in their first, second, or third year of teaching shall be evaluated a minimum of two (2) times per year using performance criteria as set forth in this policy. Classroom teachers in their fourth and fifth year of teaching shall be evaluated a minimum of one (1) time per year using performance criteria. Classroom teachers with five (5) or more years of experience, who have not received an unsatisfactory rating, shall be evaluated no more than once every three years unless the immediate supervisor determines an evaluation for a particular school employee is needed more frequently or a classroom teacher requests an evaluation for a particular school year. (West Virginia Department of Education, Policy 5310, Section 126-142-9)

The accepted form of evaluation for the state of West Virginia as adopted in Policy 5310 includes every classroom based on "programs of study, classroom climate, instructional management systems, student progress, communication, professional work habits, and technology standards” (WVDE, 2002, p. 6). Although these are broad areas of evaluation, each area is broken down into specific items that the evaluator should be looking for when observing for thirty (30) minutes in the classroom during one activity. This document is presented to principals and evaluators in order to lead the evaluator and teacher into an informal discussion of methods that worked in the classroom and procedures that need improvement. 


\section{Statement of the Problem:}

Agriculture teachers tend to find themselves working hard to gain recognition for their students through FFA Career Development Events, advancing student degrees, applying for National Chapter Awards, and filling out applications to get their students or chapter recognized at and above the state level. Every teacher's goal is for every student to have a supervised agricultural experience program knowing that only a few will attain the State or American FFA degree let alone a State or National Proficiency Award. Why is recognition for FFA chapter and agriculture program so important? Why do teachers of agriculture work so hard just to get a plaque to hang on the wall that exemplifies their accomplishments in one area of agriculture or FFA? Should we reward what the teacher does to incorporate the total agriculture program so that all students participate in the FFA, have a quality SAE, and experience things in the classroom/laboratory? The real problem exists in the fact that we teach that agriculture education is a finely tuned machine that depends on three parts to be successful. We reward and evaluate the three parts of the agriculture education curriculum separately and not as one total unit. What are the characteristics that one should examine when determining the profile of an effective agriculture program? Agriculture educators tend to emphasize one or two aspects of their program and neglect the remaining parts. Agriculture educators should be held to the highest standards possible to ensure that every agriculture student accomplishes something in all three areas of the program while enrolled. Can this be evaluated by a visit from the principal once or twice a semester? Does the standard state adopted evaluation form cover the appropriate areas to inform the agriculture educator how to improve in one or all three areas? 
Purpose of the Study:

The purpose of this study was to determine the characteristics of the agriculture educator in West Virginia. It examined the characteristics that currently existed in agriculture educators and identified areas that needed improvement in order to make sure all agriculture programs operate at the highest level.

Objectives of the Study:

The primary objective of this study was to determine the qualities possessed by agriculture educators in West Virginia. The research question that guided this study was: What characteristics were commonly associated with agricultural education teachers in a selected state? 


\section{CHAPTER II}

Review of Literature

This study was designed to establish baseline data concerning characteristics of the secondary agriculture educator in West Virginia. Information obtained will be useful to teacher educators and state supervisors in developing efficient evaluations of the agriculture teachers within their state.

Evaluation is a common practice in the education profession. Educators are often evaluated on their classroom etiquette and mannerisms. Should a universal evaluation be used for academically based secondary teachers as well as teachers with specialized vocational classes? This review examined evaluation methods currently used to compare teachers to a set of ideal characteristics.

The Handbook on Agriculture Education (Phipps \& Osborne 1988) defined several characteristics that are desirable in the agriculture educator. Some of these characteristics are:

Farm training, character and personality, rural mindedness, leadership, commitment to teaching, confidence, neatness, courtesy and manners, correct attitude, willingness to cooperate, professional ethics, willingness to work, intelligence, emotional maturity, physical abilities, health, general education, and broad interests. (p. 31-36)

A study by Miller, Kahler, and Rheault (2002) at Iowa State University established similar yet more refined characteristics that are expected in agriculture educators. They are divided into the following teacher performance areas: "productive teaching behaviors, organized structured class management, positive interpersonal relationships, professional responsibilities, and personal characteristics” (p. 37-38). 
There is a lack of extensive research in evaluation of the agriculture educator. There are characteristics that have been described in several articles and journals that discuss the abilities desired in agriculture educators.

In the instructional phase an agriculture instructor must, effectively plan for instruction, evaluate student achievement, communicate well with others, recognize achievement, motivate students, love agriculture, manage student behavior and discipline in class, encourages, councils, and advises students, uses a variety of teaching methods, incorporates science and other areas of school curriculum into instruction, has excellent knowledge of subject matter, innovative, capable of solving problems and multitasking, and is knowledgeable of teaching and learning theory. (Roberts \& Dyer, 2002)

Miller et al., (1989) state that an agriculture teacher should:

1. Develop course activities which reflect "lifelike" situations, relating current lessons to past lessons.

2. Utilize learning activities which are designed to achieve predetermined objectives for the course.

3. Motivates students by providing successful learning activities at each student's ability level, yet challenges students to higher scholastic expectations.

4. Evaluates his/her performance and accepts honest feedback from students for continued improvement.

5. Very often provides written comments on exams to facilitate student learning.

6. Will sometimes need to further explain assignments to students even after directions are given. 
7. More often than not will design educational activities for the class as a whole rather than for individual students.

8. Very often seeks the advice of experts in the subject matter he/she teaches.

9. Almost always helps students locate supplementary materials to subject matter content being covered in class. (p. 37-38)

The secondary education environment today is incredibly different than it was decades ago. More classes are required for graduation and higher standards exist for promotion. Many students do not have the ability to take an elective class for personal interest exploration because they have to load their schedules with college preparatory courses. Adding to their load, students must take high-stakes standardized tests. Throughout the spring semester a student can take the ACT, SAT, ASVAB, WestTest, Core Content Tests, as well as nine-week and semester tests for each of their classes. How much is enough?

Expectations are placed on all teachers, including agriculture teachers, to contribute to increasing test scores. Classroom instruction is only the beginning of an agriculture educator's profession. They are also required to advise the FFA Organization at the local level, as well as help students develop successful supervised agriculture experience programs. Should the agriculture educator be evaluated only on classroom instruction or should the administrator ensure the agriculture educator is incorporating all three aspects of the total agriculture education program? An agriculture educator should "have the ability to advise a local FFA chapter" (Phipps \& Osborne, 1988, p. 137). Some of the competencies that must accompany advising the FFA are, "participating in meetings, advising regarding budget and finances, assisting treasurer with financial records, helping the secretary improve records, instructing reporter in preparing articles, advising committees, assisting in applying for advanced degrees, and assisting in 
carrying out special activities” (Phipps \& Osborne, 1988 p. 139). Roberts and Dyer (2002) suggest that the agriculture instructor have a sound knowledge of FFA, actively advise the FFA chapter, and effectively prepare the students for CDEs and other FFA activities. An agriculture instructor should spend at least 22\% of their time advising the FFA or preparing for FFA activities (Miller et al., 1988). Agriculture instructors should have a high percentage of students actively participating in supervised agriculture experience programs (Miller et al., 1988). They must also have a sound knowledge of SAEs and actively supervise and encourage SAE projects for all students (Roberts \& Dyer, 2002). “One key to better teaching is to make students better learners. Through the process of teaching thinking, we can teach students how to become better learners” (Rollins \& Scanlon, 1991, p. 48). In addition to the aforementioned characteristics an agriculture educator must continue to strive for excellence in the classroom above and beyond the expectations of other teachers in the high school or vocational setting. 


\section{CHAPTER III}

Methods and Procedures

Purpose of the Study:

The purpose of this study was to determine the characteristics of the agriculture educator in West Virginia. It examined the characteristics that currently existed in agriculture educators and identified areas that needed improvement in order to make sure all agriculture programs operate at the highest level.

Objectives of the Study:

The primary objective of this study was to determine the qualities possessed by agriculture educators in West Virginia. The research question that guided this study was: What characteristics were commonly associated with agricultural education teachers in a selected state?

\section{Research Design}

A descriptive research design was used to collect data from agricultural educators in West Virginia. A survey is an attempt to collect data from members of a population in order to determine the current status of the population with respect to one or more variables. One advantage of survey research is the amount of flexibility in which it provides. It can provide several kinds of information in many different settings. The major problem with this type of research is the high non response rate.

\section{Population}

The target population for this study was all high school agriculture educators employed in West Virginia during the 2003-2004 school year. A list of names and addresses were obtained from the Agricultural and Environmental Education Department at West Virginia University. Because of the small population size $(N=97)$ a census was used. The accessible population 
consisted of 97 agriculture educators employed in West Virginia during the 2003-2004 school year.

\section{Instrumentation}

The basic characteristics of an effective agriculture teacher identified by Miller et al., (1989) were used by the researcher to develop a questionnaire on effective teachers. Reliability and validity of the survey instrument was established to eliminate measurement. An official directory from West Virginia was used to obtain information from the entire target population. This eliminated the possibility of sampling, selection, and frame errors. Recommended data collection procedures were utilized to reduce/control non-response error.

\section{Data Collection Procedures}

A cover letter was prepared that explained the study and provided instructions for completion of the questionnaire. A packet, including the cover letter, questionnaire, and self addressed return envelope was mailed to all high school agriculture educators in the accessible population. To improve the rate of return, a two-week deadline was given. A second packet was mailed to everyone who did not respond by the deadline. Fifty-seven surveys were returned for a response rate of 58.7\%. An analysis of variance was used to determine if early respondents were different than late respondents. Significant differences were found therefore generalizations were limited to the agricultural education teachers who responded to the survey. Analysis of Data

This study was designed to measure the perceptions agriculture educators have on themselves and if they consider certain factors when they assume they are successful or effective. Data were analyzed using the Statistical Package for Social Sciences (SPSS-PC) at the West Virginia University. Descriptive statistics were used to analyze data collected from 
questionnaires in the form of frequencies, percentages, and means. Data were recorded and presented in narrative as well as tabular form.

Use of Findings

Findings from this survey can be used by principals or state staff to determine proper evaluation of the effective agriculture educator, based on the characteristics found herein. 


\section{CHAPTER IV}

\section{Findings}

\section{Purpose of the Study}

The purpose of this study was to determine the characteristics of the agriculture educator in West Virginia. It examined the characteristics that currently existed in agriculture educators and identified areas that needed improvement in order to make sure all agriculture programs operate at the highest level.

Objectives of the Study

The primary objective of this study was to determine the qualities possessed by agriculture educators in West Virginia. The research question that guided this study was: What characteristics were commonly associated with agricultural education teachers in a selected state?

\section{Population}

The target population for this study was all high school agriculture educators employed in West Virginia during the 2003-2004 school year. A list of names and addresses were obtained from the Agriculture and Environmental Education Department at West Virginia University. Because of the small population size $(N=97)$ a census was used. The accessible population consisted of 97 agriculture educators employed in West Virginia during the 2003-2004 school year.

\section{Demographic Characteristics}

Using five year incremental categories, participants were asked to identify their age. Six respondents were age 21-25 years of age (10.5\%). Nine respondents were between the ages of 26 and 30 (15.8\%). Eight of the respondents were from 31-35 years (14.0\%), while 3 
respondents were from age 36-40 (5.3\%). In the age group of 41-50 years there were 16 respondents (28.1\%), while there were 14 respondents from the 51-60 years of age group (24.6\%). There was one respondent (1.8\%) in the 61 years of age and older group (see Figure 1). Years of Teaching Experience

The respondents to the questionnaire were asked to classify their years of teaching using five year increments. Thirteen respondents (23.2\%) had 1 to 5 years of teaching experience, while there were 9 respondents (16.1\%) with 6 to 10 years of experience. Three of the respondents (5.4\%) had 11 to 15 years of teaching experience. Six respondents $(10.7 \%)$ had 16 to 20 years of experience, while the experience range of 21 to 25 years of experience had 11 respondents (19.6\%). Fourteen of the respondents (25.0\%) had 26 or more years of experience. (see Figure 2)

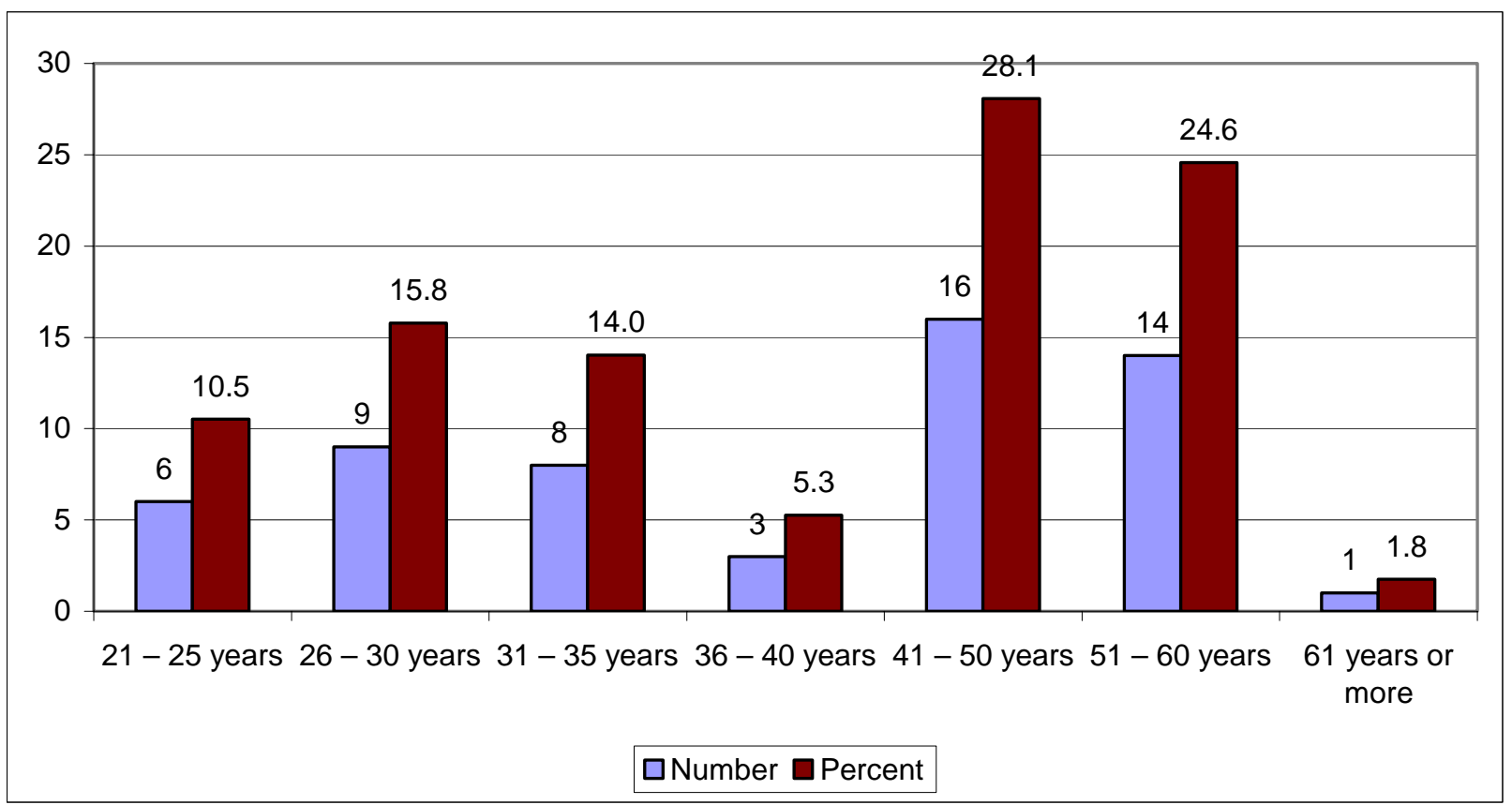

Figure 1. Distribution of Respondents by Age Group 


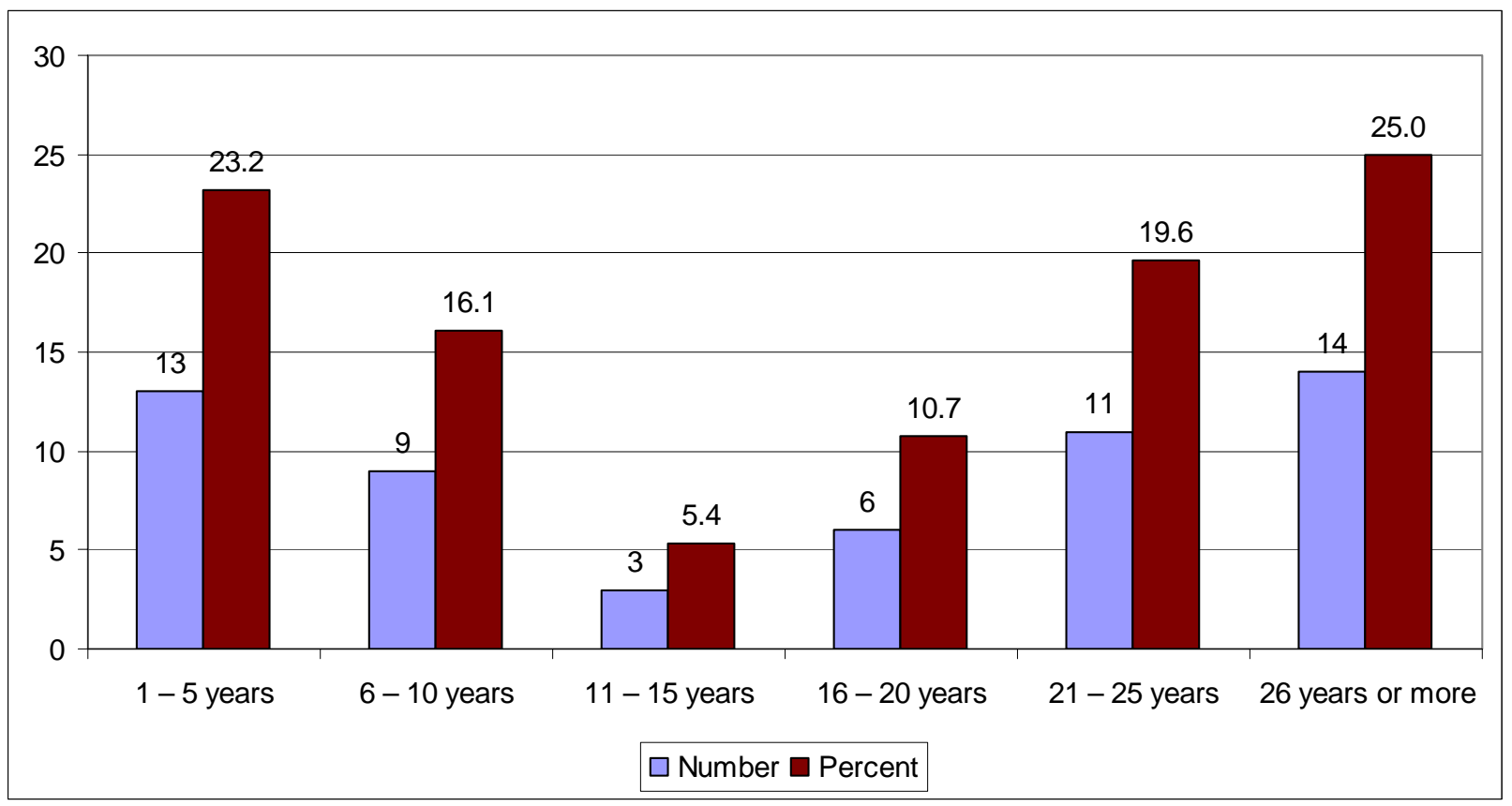

Figure 2. Years of Teaching Experience

\section{Years Lived on a Farm}

Participants were asked to give an estimate, using five-year incremental categories, of the years they had lived on a farm. Seven respondents (12.3\%) had never lived on a farm, while five respondents (8.8\%) had spent 1 to 5 years of their life on a farm. One respondent $(1.8 \%)$ had six to ten years living on a farm. Three respondents (5.3\%) had spent 11 to 15 years living on a farm, while six respondents (10.5\%) had lived on a farm for 16 to 20 years. The number of respondents that had lived on a farm for 21 to 25 years was eight (14\%). Twenty-seven respondents (47.4\%) had lived for a period of 26 years or longer on a farm (see Figure 3). 




Figure 3. Years Lived on a Farm

\section{Years Lived in Current School District}

Respondents were asked to estimate the number of years in which they have lived in their current school district. Of the fifty-seven respondents, three (5.3\%) had lived in their current school district for less than one year. Eight respondents (14.0\%) had lived from one to five years in their current school district. In the range of six to ten years living in the current school district, there were ten respondents (17.5\%), while there were three respondents $(5.3 \%)$ that had eleven to fifteen years living in their current school district. Four respondents (7.0\%) had lived sixteen to twenty years in their current school district. Six respondents (10.5\%) had lived in their current school district for twenty-one to twenty-five years, while twenty-three respondents (40.4\%) had lived longer than twenty-six years in their current school district (see Figure 4). 


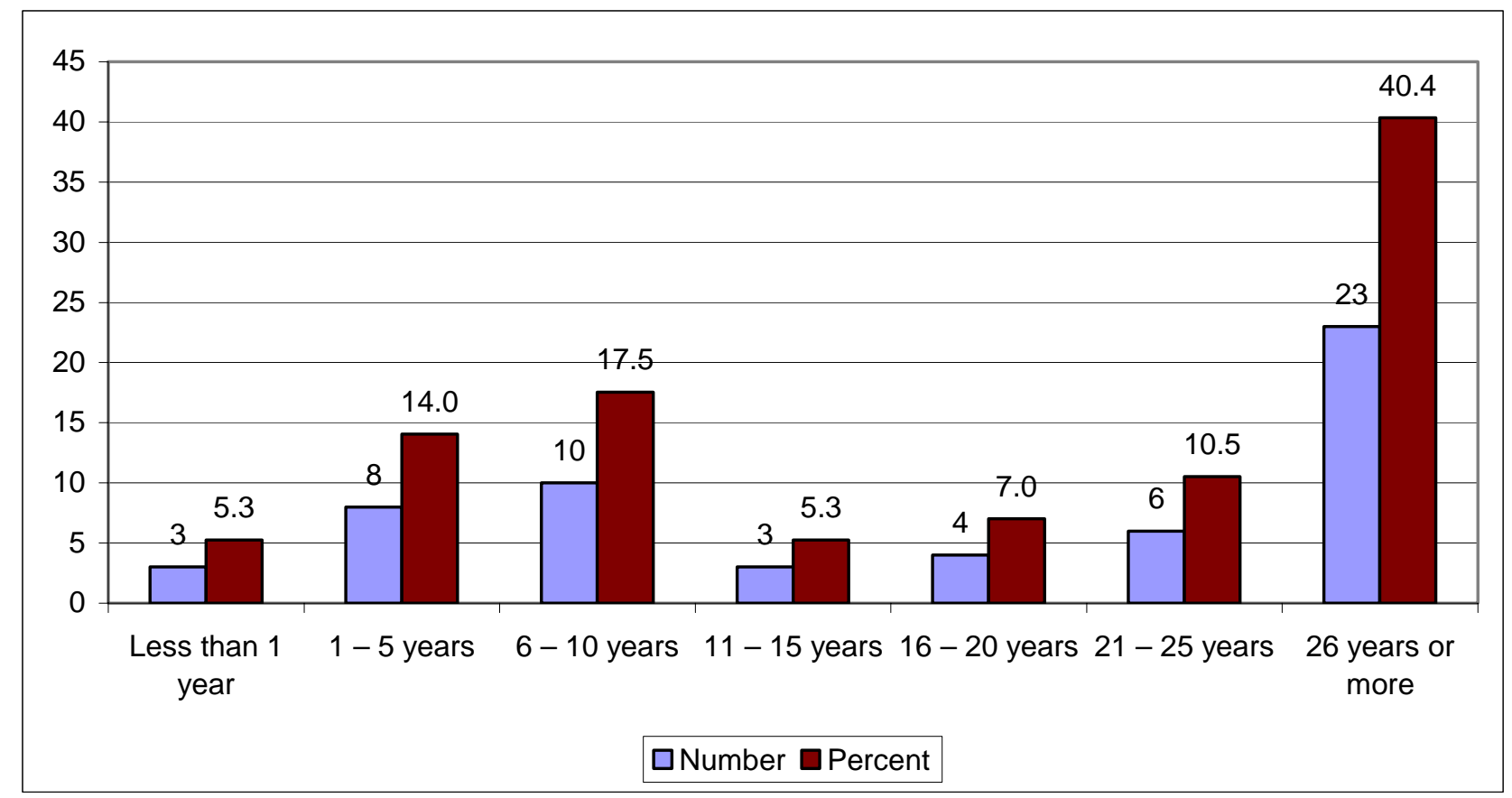

Figure 4. Years Living in Your Current School District

Number of Students with a Supervised Agriculture Experience Program

When asked the number of students in their program that currently had a supervised agriculture experience program the fifty-seven respondents to the questionnaire provided the following information. Seven respondents (12.7\%) had 0 - 25 percent of all their students having a SAE. Eleven respondents (20.0\%) had 26 - 50 percent of their students completing a SAE, while four respondents (7.3\%) had between 51 - 60 percent of their students with an SAE. Five respondents (9.1\%) had between 61 - 70 percent of their students having a SAE. In the 71 - 80 percent category there were thirteen respondents (23.6\%), while seven respondents (12.7\%) had 81 - 90 percent of their students with a SAE. Eight respondents (14.5\%) had 91 - 100 percent of their students with a SAE (see Figure 5). 


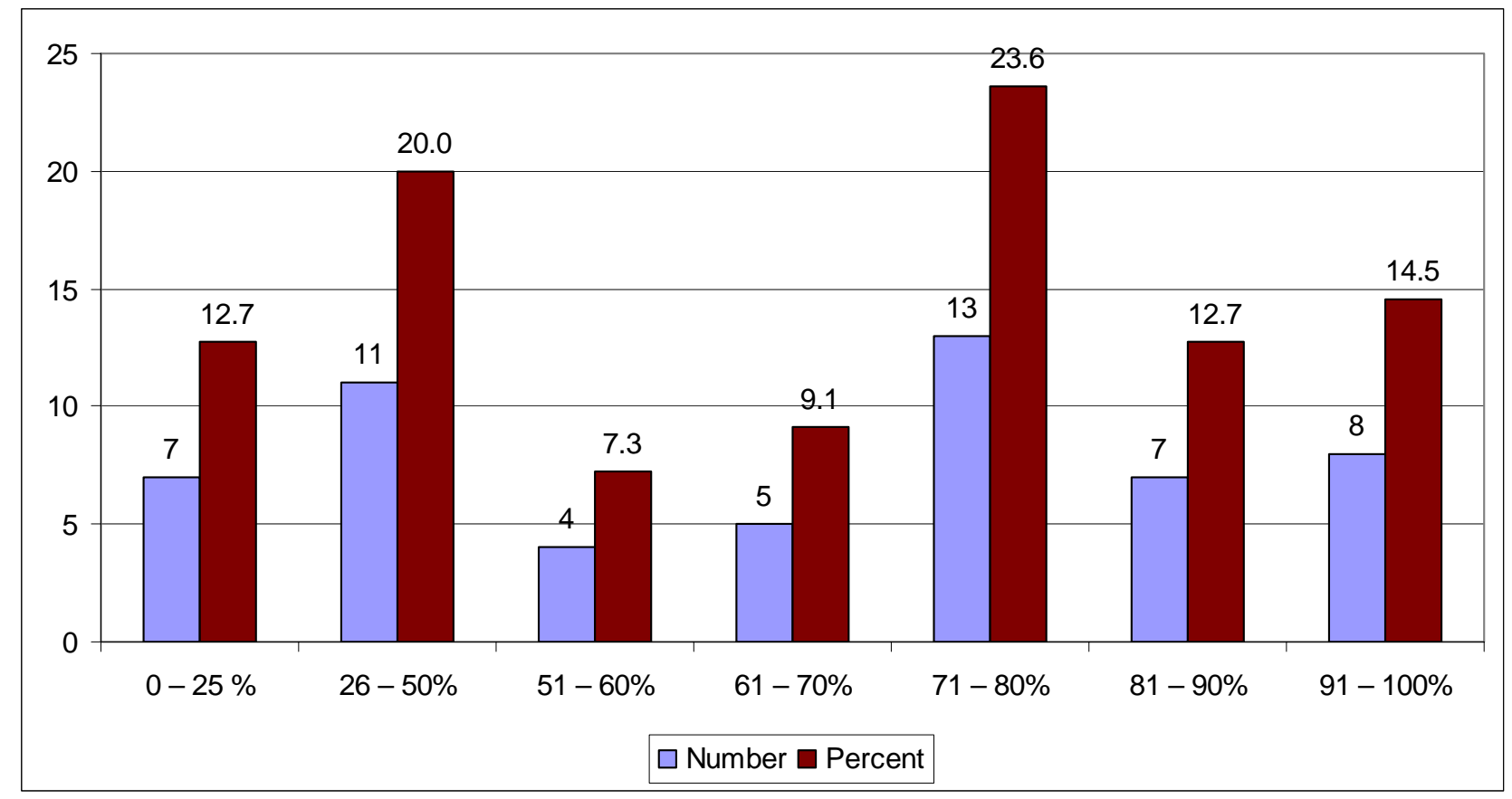

Figure 5. Percentage of Students Having a Supervised Agriculture Experience Program Percentage of Students Who Were FFA Members

Respondents were asked to estimate the percentage of students that were FFA members. Three respondents (5.3\%) had 0 - 25 percent of their students as FFA members. Eight respondents (14.0\%) had between 26 - 50 percent of their students as FFA members. Five respondents (8.8\%) had 51-60 percent of their students as FFA members, while one respondent had between 61- 70 percent of their students as FFA members. Eight respondents (14.0\%) had between 71-80 percent of their students as FFA members. The 81-90 percent category had eight respondents (14.0\%). Twenty-four respondents (42.1\%) of respondents had between 91-100 percent of their students as FFA members (see Figure 6). 


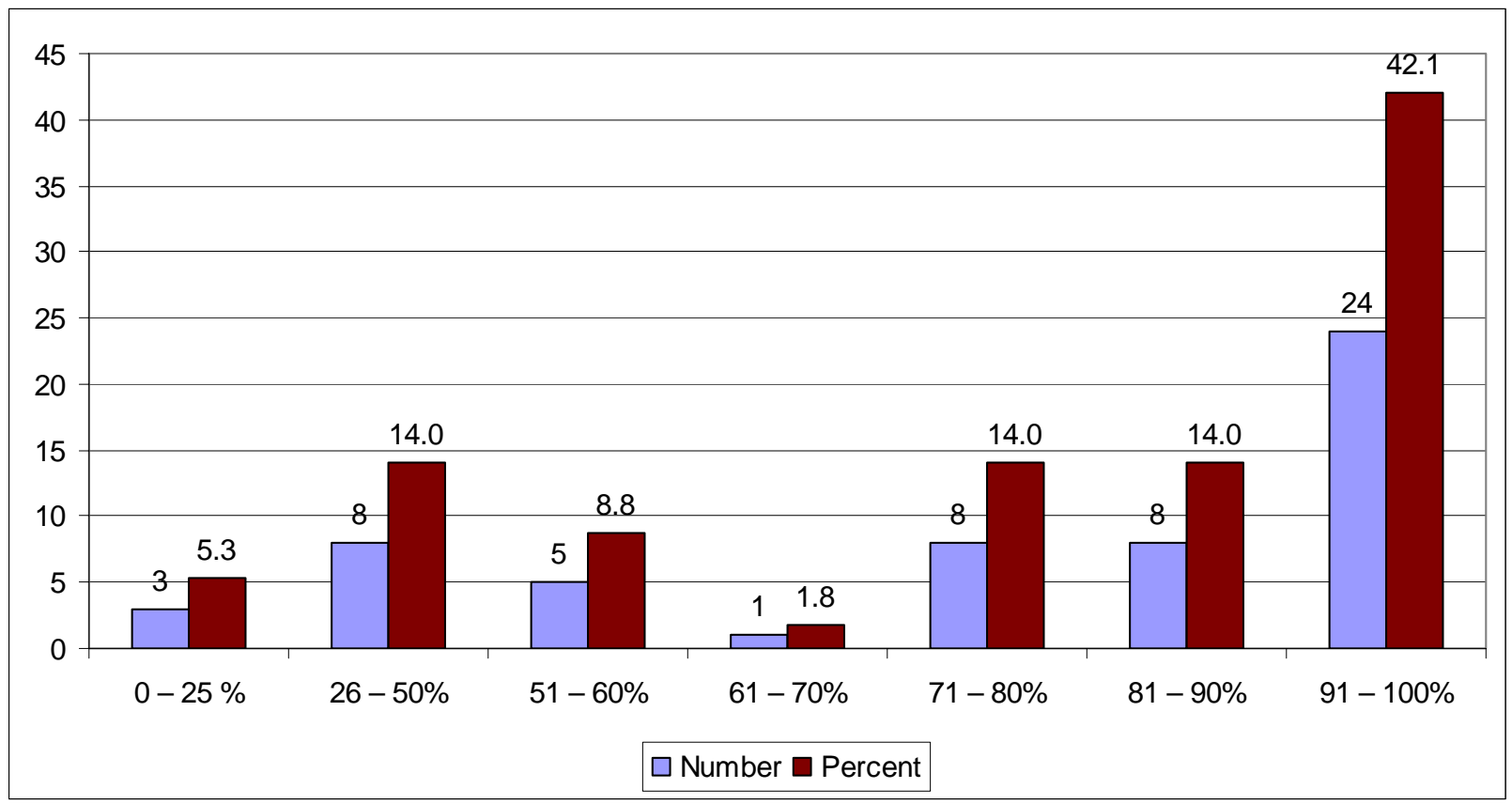

Figure 6. Percent of Students That Were FFA Members

Number of Professional Organizations

Respondents were asked to indicate the number of professional agriculture organizations in which they were a member. Thirty-nine of the 57 respondents answered as follows. Three respondents (5.3\%) were members of no professional agriculture organizations. Thirteen respondents (22.8\%) were members of one professional agriculture organization. Nine respondents (15.8\%) were members of two professional agriculture organizations, while five respondents (8.8\%) were members of three professional agriculture organizations. Three respondents (5.3\%) were members of four professional agriculture organizations. Respondents that were involved in five professional organizations numbered four (7.0\%), while two respondents (3.5\%) were involved in six professional agriculture organizations. Eighteen respondents (31.6\%) did not respond to the inquiry (see Figure 7). 


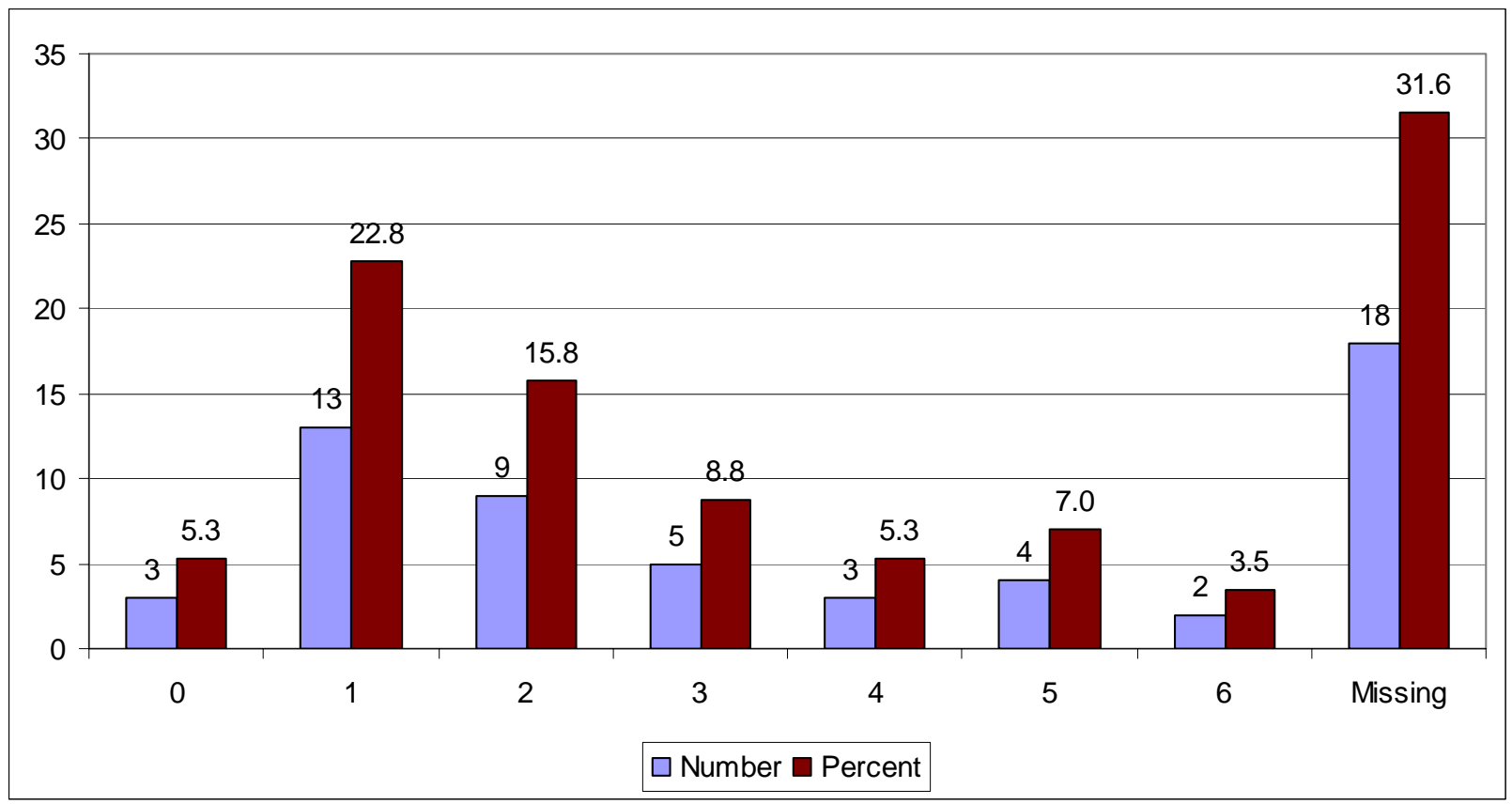

Figure 7. Professional Agriculture Organization Memberships

When asked if they had been a member of various professional agriculture organizations, respondents gave the following information. Thirteen respondents $(22.8 \%)$ indicated they were a member of the Farm Bureau. Nine respondents (15.8\%) said that they were members of the National Education Association (NEA). Nine respondents (15.8\%) were members of the West Virginia Education Association (WVEA). Thirteen respondents (22.8\%) were members of the National Association of Agricultural Educators (NAAE). Twenty respondents (35.1\%) were members of the West Virginia Association of Agriculture Educators (WVAAE). Five respondents (8.8\%) were members of the Association of Career and Technical Educators (ACTE). Three respondents (5.3\%) were members of West Virginia Career and Technical Educators (WVCTE). When asked if they were members of other professional agriculture organizations nine respondents (15.8\%) were members of other professional agricultural organizations (see Figure 8). 


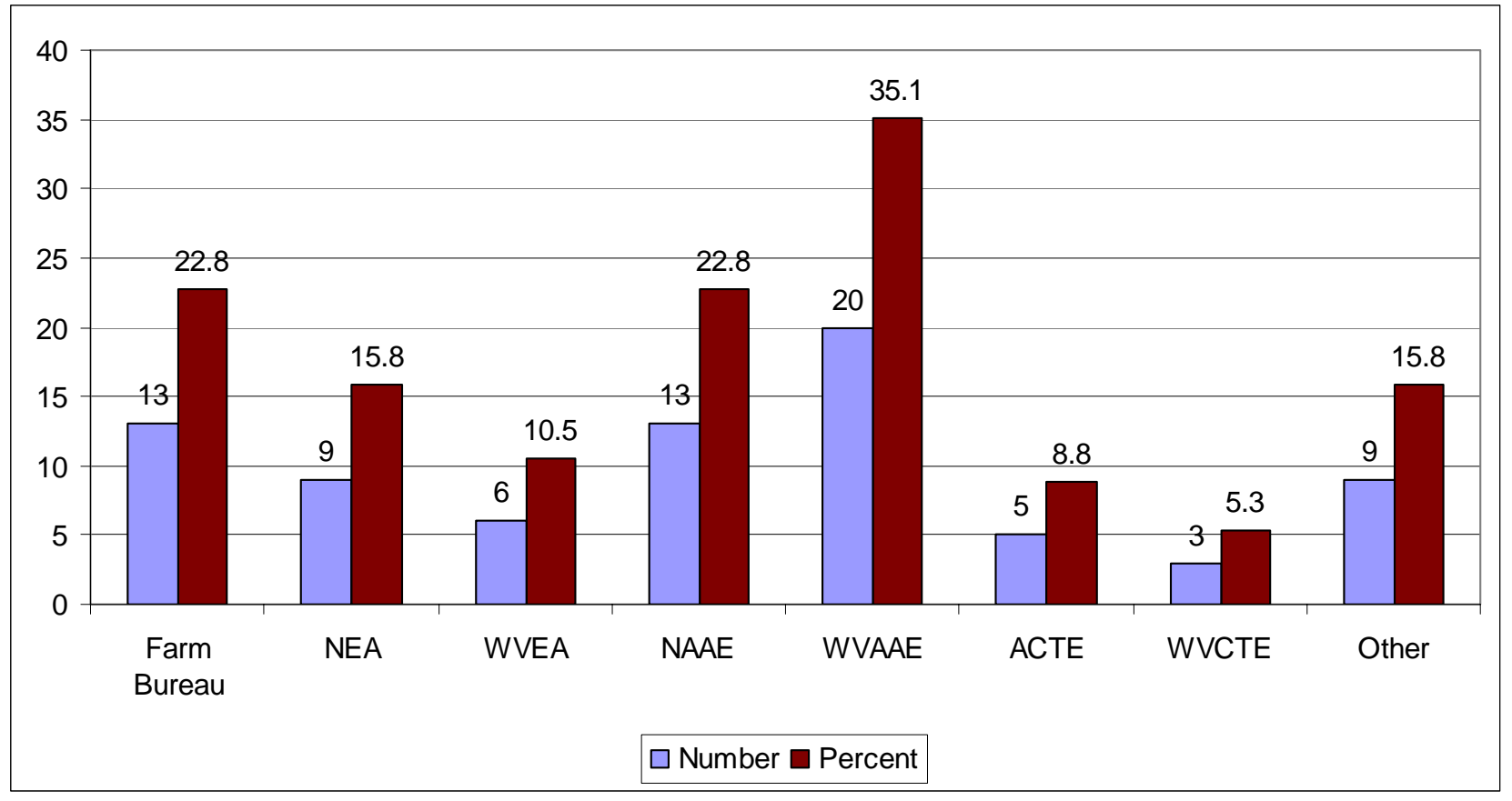

Figure 8. Membership in Professional Agriculture Organizations

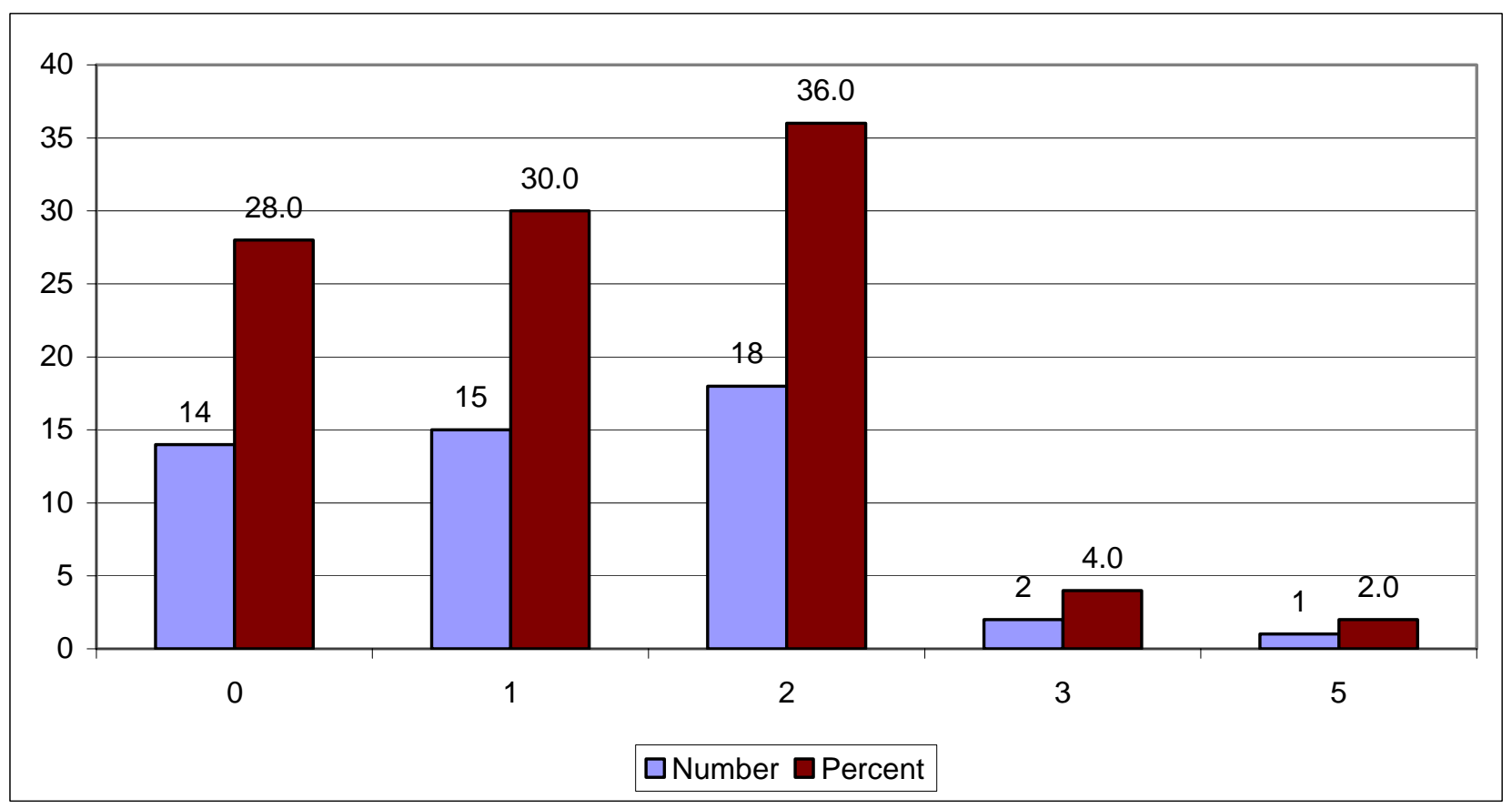

Figure 9. Membership in Civic Organizations 
Table 1

Leadership Positions in Professional Organizations

\begin{tabular}{lcccc}
\hline & M & SD & Min & Max \\
\hline $\begin{array}{l}\text { Leadership positions - } \\
\text { professional teacher } \\
\text { organizations }\end{array}$ & 1.8 & 2.55 & 0 & 12 \\
$\begin{array}{l}\text { Leadership positions - } \\
\text { professional agriculture }\end{array}$ & 1.3 & 1.71 & 0 & 8 \\
$\begin{array}{l}\text { organizations } \\
\begin{array}{l}\text { Leadership positions - civic } \\
\text { organizations }\end{array}\end{array}$ & 1.5 & 2.37 & 0 & 10 \\
$\begin{array}{l}\text { Professional development } \\
\text { workshops }\end{array}$ & 4.1 & 3.8 & 0 & 20 \\
\hline
\end{tabular}

Table 2

Characteristics of Teachers

\begin{tabular}{|c|c|c|c|c|c|c|c|c|}
\hline & \multirow[t]{2}{*}{$M$} & \multirow[t]{2}{*}{$S D$} & \multicolumn{2}{|c|}{ Sometimes } & \multicolumn{2}{|c|}{ Frequently } & \multicolumn{2}{|c|}{ Very Often } \\
\hline & & & $\mathrm{N}$ & $\%$ & $\mathrm{~N}$ & $\%$ & $\mathrm{~N}$ & $\%$ \\
\hline Classroom Instruction & 4.1 & .40 & 4 & 7.0 & 42 & 73.7 & 11 & 19.3 \\
\hline $\begin{array}{l}\text { Organized, Structures, and } \\
\text { Class Management }\end{array}$ & 4.0 & .32 & 2 & 3.5 & 51 & 89.5 & 4 & 7.0 \\
\hline $\begin{array}{l}\text { Professional Responsibilities } \\
\text { and Personal Characteristics }\end{array}$ & 4.2 & .43 & 3 & 5.3 & 37 & 64.9 & 17 & 29.8 \\
\hline
\end{tabular}

\section{Characteristics of West Virginia Agriculture Teachers}

When asked how often they developed course activities that reflected lifelike situation, eight (14.0\%) responded that they sometimes completed this duty. Twenty-seven (47.4\%) of the respondents frequently reflected lifelike situations in their classroom. Twenty-two (38.6\%) of the respondents reflected lifelike situations very often in their classroom. (see Table 3)

When asked how often they related current lessons to past lessons, one (1.8\%) responded that they never completed this duty. Four (7.0\%) of the respondents sometimes related current lessons to past lessons in their classroom. Twenty-five (43.9\%) of the respondents frequently 
related current lessons to past lessons in their classroom, while 27 (47.4\%) responded that they very often related current lessons to past lessons in their classroom.

When asked how often they used learning activities designed to achieve objectives, one (1.8\%) responded that they only rarely completed this duty. Four (7.1\%) of the respondents had sometimes used learning activities designed to achieve objectives in their classroom. Thirtythree (58.9\%) of the respondents had frequently used learning activities in their classroom to achieve objectives, while 18 (32.1\%) of respondents had very often used learning activities designed to achieve objectives.

Respondents were asked how often they used written lesson plans, two (3.6\%) completed written lesson plans rarely. Six (10.7\%) respondents sometimes used written lesson plans. Sixteen (28.6\%) respondents frequently used written lesson plans, while 32 (57.1\%) used written lesson plans very often.

When asked how often they created their own lesson plans, two (3.5\%) respondents only sometimes completed this activity. Eighteen (31.6\%) respondents had frequently created their own lesson plans, while 37 (64.9\%) created their own lesson plans very often.

Twelve respondents (21.1\%) sometimes provided successful learning activities at each student's ability levels. Twenty-nine (50.9\%) respondents frequently provided successful learning activities at each student's ability level, while 16 (28.1\%) respondents had completed this task very often in their classroom.

When asked if they challenged students to higher scholastic expectations, three (5.3\%) respondents had sometimes completed this task. Twenty-nine (50.9\%) respondents had frequently challenged their students to higher scholastic expectations, while 25 (43.9\%) respondents very often challenged their students to higher scholastic expectations. 
One (1.8\%) respondent had used motivation (interest approach) to create a felt need on why the students should study the topic. Ten (17.5\%) respondents had only sometimes used this method. Eighteen (31.6\%) respondents had frequently used motivation to create a felt need on why the students should study the topic. Twenty-eight (49.1\%) responded that they had very often motivated students to have a felt need to study the topic.

When asked how often they had accepted honest feedback from students, nine (15.8\%) sometimes accepted honest feedback from students. Nineteen (33.3\%) respondents would frequently accept honest feedback from their students, while 29 (50.9\%) very often accepted the honest feedback from the students.

One (1.8\%) respondent never provided written comments on exams to facilitate student learning. Five (8.8\%) respondents rarely provided written comments on exams, while 23 (40.4\%) respondents sometimes provided written comments on exams to facilitate student learning. Nineteen (33.3\%) frequently completed this task. Nine (15.8\%) provided written comments on exams very often.

When asked how often they explained assignments even after the directions were given, nine (15.8\%) only sometimes completed this task. Twenty-four (42.1\%) respondents frequently explained assignments and 24 (42.1\%) very often explained assignments to students after the directions had been given.

When asked if they designed educational activities for the class as a whole rather than for individual students, one (1.8\%) respondent rarely had completed this in their classroom. Eleven (19.3\%) respondents had only sometimes designed educational activities for the class as a whole and not for individual students. Thirty-four (59.6\%) respondents had frequently designed 
educational activities for the class as a whole and not for individual students, while 11(19.3\%) had very often completed this same activity.

When asked how often they sought advice from experts, four (7.0\%) respondents had rarely used this resource. Sixteen (28.1\%) respondents had sometimes sought advice from experts, while 20 (35.1\%) frequently sought advice from experts. Seventeen (29.8\%) respondents very often sought the advice of experts.

Four (7.0\%) respondents never used a pre-organizer to help direct student thinking when they enter the classroom. Seventeen (29.8\%) rarely used a pre-organizer to help direct student thinking when they enter the classroom. Twenty-two (38.6\%) respondents sometimes used a pre-organizer to direct student thinking, while ten (17.5\%) used this method frequently when students entered the classroom. Four (7.0\%) respondents used a pre-organizer to help direct student thinking as they entered the classroom very often.

When asked how often they helped students locate supplementary materials to the subject matter content covered in class, 25 (43.9\%) respondents indicated they would do this sometimes, while 24 (42.1\%) responded that they helped students locate supplementary materials frequently. Eight (14.0\%) respondents very often helped students locate supplementary materials to the subject matter content covered in class.

Eight (14.0\%) respondents sometimes promote reading skill development in their classroom. Thirty four (59.6\%) respondents frequently promoted reading skill development in their classroom, while eight (14.0\%) promoted reading in their classroom very often.

When asked how often they promoted writing skills in the classroom, nine (15.8\%) sometimes promoted this skill, while 34 (59.6\%) respondents frequently promoted writing skills. Fourteen (24.6\%) respondents very often promoted writing skill within their classroom. 
One (1.8\%) respondent never promotes math skill development in their classes, while seven (12.5\%) respondents sometimes promoted this skill development in their students. Thirtytwo (57.1\%) respondents promoted math skill development in their classroom frequently, and 16 (28.6\%) respondents very often promoted math skill development in their classroom.

\section{Organized Structures and Class Management}

When asked how often they utilized long range plans to guide improvement of the agricultural education program, one (1.8\%) respondent had rarely completed these plans, while $13(23.2 \%)$ respondents sometimes utilized long range plans to guide improvement of the agricultural education program. Twenty-four (42.9\%) respondents frequently utilized long range plans to guide improvement of the agricultural education program. Eighteen (32.1\%) respondents very often completed these plans.

One (1.8\%) respondent had never made long range plans that are based upon an up to date course of instruction. Six (10.7\%) respondents sometimes made long range planes based upon an up to date course of instruction, while 24 (42.9\%) frequently made long range plans based upon an up to date course of instruction. Twenty-five (44.6\%) respondents very often made long range plans based upon an up to date course of instruction.

When asked how often their course of instruction was approved by their advisory committee, four (7.3\%) respondents had both never had their course of instruction approved by their advisory committee. Four (7.3\%) respondents rarely had their course of instruction approved by their advisory committee. Seven (12.7\%) respondents sometimes had their course of instruction approved by their advisory committee, while 17 (30.9\%) respondents frequently had their course of instruction approved by their advisory committee. Twenty-three (41.8\%) respondents very often had their course of instruction approved by their advisory committee. 
When asked how often they established a given set of rules and procedures to manage student behavior, 36 (64.3\%) respondents had very often completed this task and 15 (26.8\%) respondents had frequently established a given set of rules and procedures to manage student behavior. Five (8.9\%) respondents sometimes established a given set of rules and procedures to manage student behavior.

Eighteen (32.1\%) respondents sometimes allowed for student input when establishing classroom rules. Thirteen (23.2\%) respondents had rarely allowed for student input when establishing classroom rules. Thirteen (23.2\%) respondents frequently allowed for student input when establishing classroom rules, while eight (14.3\%) respondents very often allowed students to help in completing this task. Four (7.1\%) respondents had never allowed for student input in establishing classroom rules.

Sixteen (28.1\%) respondents had sometimes adjusted and rearranged the classroom to provide for a variety of learning activities within the classroom. Sixteen (28.1\%) respondents had very often adjusted and rearranged the classroom to provide for a variety of learning activities within the classroom. Twenty-three (40.4\%) respondents frequently adjusted and rearranged the classroom to provide for a variety of learning activities within the classroom, while two (3.5\%) respondents rarely completed this task.

Thirty (53.6\%) respondents had very often confronted students when they were not on the assigned task, while 24 (42.9\%) respondents frequently confronted students when they were not on the assigned task. Two (3.6\%) respondents sometimes confronted students when they were not on the assigned task.

Twenty-six (45.6\%) respondents very often presented information on the blackboard/whiteboard which can be read by all students. Twenty-three (40.4\%) respondents 
presented information on the blackboard/whiteboard which can be read by all students frequently, while eight (14.0\%) respondents sometimes presented information on the blackboard/whiteboard which can be read by all students.

Twenty-two (38.6\%) respondents had sometimes used textbooks to provide most of the printed information given to the students. Twenty-two (38.6\%) respondents had frequently used textbooks to provide most of the printed information given to the students. Nine (15.8\%) respondents had very often used textbooks to provide most of the printed information to the students, while four (7.0\%) respondents rarely used textbooks to provide most of the printed information to the students.

When asked how often they encouraged professionally friendly relationships with students, 27 (48.2\%) respondents frequently completed this task and 27 (48.2\%) respondents very often completed this task. Two (3.6) respondents sometimes encouraged professionally friendly relationships with students.

Forty (71.4\%) respondents very often encouraged respectful relationships with students, while 16 (28.6\%) respondents had frequently encouraged respectful relationships with students.

Twenty-two (38.6\%) respondents rarely used sarcasm in the classroom; while twenty-one (36.8\%) respondents sometimes used sarcasm in the classroom. Sarcasm was used frequently in eight (14.0\%) respondent's classrooms, and six (10.5\%) respondents never used sarcasm in the classroom.

Constructive criticism of students for further educational improvement never occurred in one (1.8\%) respondent's classroom. Two (3.5\%) respondents rarely constructively criticized students for further educational improvement and two (3.5\%) respondents very often provided constructive criticism. Thirty (52.6\%) respondents frequently constructively criticized students 
for further educational improvement, while 22 (38.6\%) respondents had sometimes constructively criticized their students.

Twenty-nine (50.9\%) respondents frequently kept informed about students needing special assistance. Twenty (35.1\%) respondents very often kept informed about students needing special assistance, eight (14.0\%) respondents only sometimes kept informed about students needing special assistance.

Very often 31 (54.4\%) respondents were willing to provide time for any student needing extra help. Twenty-one (36.8\%) respondents frequently provided time for any student needing extra help. Five (8.8\%) respondents sometimes provided time for any student needing extra help.

Involvement of parents of students in program related activities occurred frequently in 22 (38.6\%) respondents programs. Very often, 19 (33.3\%) respondents involved parents of students in program related activities, and 13 (22.8\%) sometimes involved parents of students in program related activities. Three (5.3\%) respondents rarely involved parents of students in program related activities.

Teaching ideas were rarely shared with other teachers in four (7.0\%) respondent's schools; while 14 (24.6\%) respondents very often shared ideas with other teachers in their schools. Nineteen (33.3\%) respondents shared ideas with other teachers in their schools sometimes. Twenty (35.1\%) respondents frequently shared ideas with other teachers in their schools.

When asked how often they categorized students by their needs (cultural, academic, intellectual, etc.), 23 (40.4\%) respondents sometimes categorized their students; while eight (14.0\%) respondents frequently categorized their students according to the needs. Fourteen 
(24.6\%) respondents rarely categorized their students according to their needs and nine (15.8\%) respondents never categorized their students according to their needs. Three (5.3\%) respondents very often categorized their students based on their needs.

Thirty-three (58.9\%) respondents recognized their students very often for their efforts. Twenty-two (39.3\%) respondents frequently recognized their students for their efforts. One (1.8\%) respondent sometimes recognized their students for their efforts.

\section{Professional Responsibilities}

When asked how often they completed their duties in a timely manner, 29 (50.9\%) respondents frequently completed their duties in a timely manner. Twenty-two (38.6\%) respondents very often completed their duties in a timely manner, while five (8.8\%) respondents sometimes completed their duties in a timely manner. One (1.8\%) respondent rarely completed their duties in a timely manner.

Thirty-four (59.6\%) respondents frequently kept abreast of new developments within their profession. Eighteen (31.6\%) respondents very often kept abreast of new developments within their profession, while five (8.8\%) respondents only sometimes kept abreast of new developments within their profession.

When asked how often they bypassed school policy when the situation warranted it, one (1.8\%) respondent very often bypassed school policy when the situation warranted it, while 13 (22.8\%) respondents never bypassed school policy. Three (5.3\%) respondents frequently bypassed school policy when the situation warranted it, and 21 (36.8\%) respondents only rarely bypassed school policy when the situation warranted it. Nineteen (33.3\%) respondents sometimes bypassed school policy when the situation warranted it. 


\section{Personal Characteristics}

When asked how often they displayed personality traits such as humor and patience which promote positive interaction with students, 29 (50.9\%) respondents very often displayed this trait. Twenty-eight (49.1\%) respondents frequently displayed personality traits such as humor and patience which promote positive interactions with students.

One (1.8\%) respondent rarely felt enthusiastic towards their work, while 29 (47.4\%) respondents frequently felt enthusiastic towards their work. Twenty-three (40.4\%) respondents very often felt enthusiastic towards their work. Six (10.5\%) respondents sometimes felt enthusiastic toward their work.

When asked if how often they felt capable of handling any challenges associated with their work, seven (12.3\%) respondents sometimes felt that they could deal with the challenges, while 23 (40.4\%) respondents very often felt that they could deal with the challenges associated with their work. Twenty-seven (47.4\%) respondents frequently could deal with the challenges associated with their work.

Thirty-four (59.6\%) respondents can cope with the changing situations occurring within the classroom environment. Seventeen (29.8\%) respondents could very often cope with the changing situations occurring within the classroom environment. Six (10.5\%) respondents sometimes could deal with the changing situations occurring within the classroom environment. 
Table 3

Characteristics of West Virginia Agriculture Teachers

\begin{tabular}{|c|c|c|c|c|c|c|c|c|c|c|}
\hline & \multicolumn{2}{|c|}{ Never } & \multicolumn{2}{|c|}{ Rarely } & \multicolumn{2}{|c|}{ Sometimes } & \multicolumn{2}{|c|}{ Frequently } & \multicolumn{2}{|c|}{ Very Often } \\
\hline & $N$ & $\%$ & $N$ & $\%$ & $N$ & $\%$ & $N$ & $\%$ & $N$ & $\%$ \\
\hline $\begin{array}{l}\text { Develop course activities that reflected } \\
\text { lifelike situations }\end{array}$ & 0 & 0.0 & 0 & 0.0 & 8 & 14.0 & 27 & 47.4 & 22 & 38.6 \\
\hline Related current lessons to past lessons & 1 & 1.8 & 0 & 0.0 & 4 & 7.0 & 25 & 43.9 & 27 & 47.4 \\
\hline $\begin{array}{l}\text { Used learning activities designed to } \\
\text { achieve objectives }\end{array}$ & 0 & 0.0 & 1 & 1.8 & 4 & 7.1 & 33 & 58.9 & 18 & 32.1 \\
\hline Written lesson plans & 0 & 0.0 & 2 & 3.6 & 6 & 10.7 & 16 & 28.6 & 32 & 57.1 \\
\hline Create my own lesson plans & 0 & 0.0 & 0 & 0.0 & 2 & 3.5 & 18 & 31.6 & 37 & 64.9 \\
\hline $\begin{array}{l}\text { Provide successful learning activities at } \\
\text { students ability level }\end{array}$ & 0 & 0.0 & 0 & 0.0 & 12 & 21.1 & 29 & 50.9 & 16 & 28.1 \\
\hline $\begin{array}{l}\text { Challenge students to higher scholastic } \\
\text { expectations }\end{array}$ & 0 & 0.0 & 0 & 0.0 & 3 & 5.3 & 29 & 50.9 & 25 & 43.9 \\
\hline Use motivation to create a felt need & 0 & 0.0 & 1 & 1.8 & 10 & 17.5 & 18 & 31.6 & 28 & 49.1 \\
\hline Accept honest feedback from students & 0 & 0.0 & 0 & 0.0 & 9 & 15.8 & 19 & 33.3 & 29 & 50.9 \\
\hline Provide written comments on exams & 1 & 1.8 & 5 & 8.8 & 23 & 40.4 & 19 & 33.3 & 9 & 15.8 \\
\hline $\begin{array}{l}\text { Explain assignments to students even after } \\
\text { directions are given }\end{array}$ & 0 & 0.0 & 0 & 0.0 & 9 & 15.8 & 24 & 42.1 & 24 & 42.1 \\
\hline $\begin{array}{l}\text { Use a pre-organizer to help direct student } \\
\text { thinking }\end{array}$ & 4 & 7.0 & 17 & 29.8 & 22 & 38.6 & 10 & 17.5 & 4 & 7.0 \\
\hline
\end{tabular}


Table 3 (Continued)

Characteristics of West Virginia Agriculture Teachers

\begin{tabular}{|c|c|c|c|c|c|c|c|c|c|c|}
\hline & \multicolumn{2}{|c|}{ Never } & \multicolumn{2}{|c|}{ Rarely } & \multicolumn{2}{|c|}{ Sometimes } & \multicolumn{2}{|c|}{ Frequently } & \multicolumn{2}{|c|}{ Very Often } \\
\hline & $N$ & $\%$ & $N$ & $\%$ & $N$ & $\%$ & $N$ & $\%$ & $N$ & $\%$ \\
\hline $\begin{array}{l}\text { Help students locate supplementary } \\
\text { materials }\end{array}$ & 0 & 0.0 & 0 & 0.0 & 25 & 43.9 & 24 & 42.1 & 8 & 14.0 \\
\hline Promote reading skill development & 0 & 0.0 & 0 & 0.0 & 8 & 14.0 & 34 & 59.6 & 15 & 26.3 \\
\hline Promote writing skill development & 0 & 0.0 & 0 & 0.0 & 9 & 15.8 & 34 & 59.6 & 14 & 24.6 \\
\hline Promote math skill development & 1 & 1.8 & 0 & 0.0 & 7 & 12.5 & 32 & 57.1 & 16 & 28.6 \\
\hline $\begin{array}{l}\text { Utilize long range plans to guide program } \\
\text { improvement }\end{array}$ & 0 & 0 & 1 & 1.8 & 13 & 23.2 & 24 & 42.9 & 18 & 32.1 \\
\hline $\begin{array}{l}\text { Long range plans are based on an up-to- } \\
\text { date course of instruction }\end{array}$ & 1 & 1.8 & 0 & 0 & 6 & 10.7 & 24 & 42.9 & 25 & 44.6 \\
\hline $\begin{array}{l}\text { Course of instruction approved by advisory } \\
\text { committee }\end{array}$ & 4 & 7.3 & 4 & 7.3 & 7 & 12.7 & 17 & 30.9 & 23 & 41.8 \\
\hline $\begin{array}{l}\text { Establish set of rules to manage student } \\
\text { behavior }\end{array}$ & 0 & 0 & 0 & 0 & 5 & 8.9 & 15 & 26.8 & 36 & 64.3 \\
\hline Allow for student input in classroom rules & 4 & 7.1 & 13 & 23.2 & 18 & 32.1 & 13 & 23.2 & 8 & 14.3 \\
\hline Adjust and rearrange the classroom & 0 & 0 & 2 & 3.5 & 16 & 28.1 & 23 & 40.4 & 16 & 28.1 \\
\hline $\begin{array}{l}\text { Confront students when not on assigned } \\
\text { task }\end{array}$ & 0 & 0 & 0 & 0 & 2 & 3.6 & 24 & 42.9 & 30 & 53.6 \\
\hline $\begin{array}{l}\text { Information on blackboard can be read by } \\
\text { all students }\end{array}$ & 0 & 0 & 0 & 0 & 8 & 14.0 & 23 & 40.4 & 26 & 45.6 \\
\hline
\end{tabular}


Table 3 (Continued)

Characteristics of West Virginia Agriculture Teachers

\begin{tabular}{|c|c|c|c|c|c|c|c|c|c|c|}
\hline & \multicolumn{2}{|c|}{ Never } & \multicolumn{2}{|c|}{ Rarely } & \multicolumn{2}{|c|}{ Sometimes } & \multicolumn{2}{|c|}{ Frequently } & \multicolumn{2}{|c|}{ Very Often } \\
\hline & $N$ & $\%$ & $N$ & $\%$ & $N$ & $\%$ & $N$ & $\%$ & $N$ & $\%$ \\
\hline $\begin{array}{l}\text { Encourage professionally relationships } \\
\text { with students }\end{array}$ & 0 & 0 & 0 & 0 & 2 & 3.6 & 27 & 48.2 & 27 & 48.2 \\
\hline $\begin{array}{l}\text { Encourage respectful relationships with } \\
\text { students }\end{array}$ & 0 & 0 & 0 & 0 & 0 & 0 & 16 & 28.6 & 40 & 71.4 \\
\hline Use sarcasm in the classroom & 6 & 10.5 & 22 & 38.6 & 21 & 36.8 & 8 & 14.0 & 0 & 0 \\
\hline Constructively criticize students & 1 & 1.8 & 2 & 3.5 & 22 & 38.6 & 30 & 52.6 & 2 & 3.5 \\
\hline $\begin{array}{l}\text { Keep informed about students needing } \\
\text { special assistance }\end{array}$ & 0 & 0 & 0 & 0 & 8 & 14.0 & 29 & 50.9 & 20 & 35.1 \\
\hline $\begin{array}{l}\text { Willingly provide time for any student } \\
\text { needing extra help }\end{array}$ & 0 & 0 & 0 & 0 & 5 & 8.8 & 21 & 36.8 & 31 & 54.4 \\
\hline $\begin{array}{l}\text { Involve parents of students in program } \\
\text { related activities }\end{array}$ & 0 & 0 & 3 & 5.3 & 13 & 22.8 & 22 & 38.6 & 19 & 33.3 \\
\hline $\begin{array}{l}\text { Share teaching ideas with other teachers in } \\
\text { the school }\end{array}$ & 0 & 0 & 4 & 7.0 & 19 & 33.3 & 20 & 35.1 & 14 & 24.6 \\
\hline Categorize students by their needs & 9 & 15.8 & 14 & 24.6 & 23 & 40.4 & 8 & 14.0 & 3 & 5.3 \\
\hline Recognize students for their efforts & 0 & 0 & 0 & 0 & 1 & 1.8 & 22 & 39.3 & 33 & 58.9 \\
\hline Complete duties in a timely manner & 0 & 0 & 1 & 1.8 & 5 & 8.8 & 29 & 50.9 & 22 & 38.6 \\
\hline Keep abreast of new developments & 0 & 0 & 0 & 0 & 5 & 8.8 & 34 & 59.6 & 18 & 31.6 \\
\hline
\end{tabular}


Table 3 (Continued)

Characteristics of West Virginia Agriculture Teachers

\begin{tabular}{|c|c|c|c|c|c|c|c|c|c|c|}
\hline & \multicolumn{2}{|c|}{ Never } & \multicolumn{2}{|c|}{ Rarely } & \multicolumn{2}{|c|}{ Sometimes } & \multicolumn{2}{|c|}{ Frequently } & \multicolumn{2}{|c|}{ Very Often } \\
\hline & $N$ & $\%$ & $N$ & $\%$ & $N$ & $\%$ & $N$ & $\%$ & $N$ & $\%$ \\
\hline $\begin{array}{l}\text { Participate in workshops, field days, and } \\
\text { seminars }\end{array}$ & 1 & 1.8 & 2 & 3.5 & 12 & 21.1 & 20 & 35.1 & 22 & 38.6 \\
\hline $\begin{array}{l}\text { Bypass school policy when the conditions } \\
\text { warrant }\end{array}$ & 13 & 22.8 & 21 & 36.8 & 19 & 33.3 & 3 & 5.3 & 1 & 1.8 \\
\hline $\begin{array}{l}\text { Display personality traits such as humor } \\
\text { and patience }\end{array}$ & 0 & 0 & 0 & 0 & 0 & 0 & 28 & 49.1 & 29 & 50.9 \\
\hline Feel enthusiastic toward my work & 0 & 0 & 1 & 1.8 & 6 & 10.5 & 27 & 47.4 & 23 & 40.4 \\
\hline $\begin{array}{l}\text { Feel capable of handling any challenges } \\
\text { associated with work }\end{array}$ & 0 & 0 & 0 & 0 & 7 & 12.3 & 27 & 47.4 & 23 & 40.4 \\
\hline $\begin{array}{l}\text { Cope with the changing situations in } \\
\text { classroom environment }\end{array}$ & 0 & 0 & 0 & 0 & 6 & 10.5 & 34 & 59.6 & 17 & 29.8 \\
\hline
\end{tabular}




\section{CHAPTER V}

\section{Summary, Conclusions, and Recommendations}

Purpose of the Study:

The purpose of this study was to determine the characteristics of a successful agriculture educator. It examined the characteristics that currently existed in agriculture educators and identified areas that needed improvement in order to make sure all agriculture programs operate at the highest level. The final result will be an evaluation form that can be used to evaluate the total program of agricultural education and give the agricultural educator immediate input about areas that need improved.

Objectives of the Study:

The primary objective of this study was to determine the qualities possessed by agriculture educators in West Virginia. The research question that guided this study was: What characteristics were commonly associated with agricultural education teachers in a selected state?

Population

The target population for this study was all high school agriculture educators employed in West Virginia during the 2003-2004 school year. A list of names and addresses were obtained from the Agriculture and Environmental Education Department at West Virginia University. Because of the small population size $(N=97)$ a census was used, therefore, the accessible population consisted of 97 agriculture educators employed in West Virginia during the 20032004 school year. 


\section{Summary}

The data collected from the 57 respondents that were agriculture teachers in West Virginia resulted in $28.1 \%$ of them being from ages $41-50$, and $24.6 \%$ were from ages 51-60. This shows that over half of the agriculture teachers in the data were between the ages of 41 and 60. These teachers are set in their ways and have had an immense amount of time to work through all problems that could potentially be presented in a classroom. There were thirteen respondents (23.2\%) that had between one and five years of experience and fourteen respondents had twenty-six or more years of experience. This is an important comparison that shows that even though half of the respondents were from forty-one and sixty years of age, the majority of respondents were on opposite ends of the spectrum of teaching experience.

Another statistic that makes itself prominent was that twenty-seven respondents (47.4\%) had lived on a farm for at least twenty-six years of their life. Agriculture education can also be taught by persons that have not grown up or currently live on a farm. Seven $(12.3 \%)$ of the respondents didn’t live on a farm at any point. This goes against the research presented previously that agriculture educators should have farm experience in order to be successful in teaching the subject matter. Practical experience on a farm allows examples to be used in the classroom more readily than non-experiential examples.

Continuing with the comparative demographic information would lead us to the logical question, of how long has the teacher lived in their current school district. Almost half (40.4\%) of the respondents had lived in their current school district for twenty-six years or longer. Combining the first two categories gives us approximately 20 percent of the respondents living in their current school district for less than five years. 
Supervised Agriculture Experience Programs (SAE's) are considered one of the three basic instructional necessities of the agriculture education program. Respondents to this questionnaire were varied in their response. Eight respondents (14.5\%) had between 91 and 100 percent of their students having an SAE. Eleven respondents (19.3\%) had less than fifty percent of their students with an SAE. Therefore approximately eighty percent of the respondents had half or more of their students with a SAE. With numbers comparative to that one would be curious as to the number of members in the FFA organization? Twenty-four respondents had between 91 and 100 percent of their students belonging to the National FFA Organization. Eleven respondents (19.3\%) had less than fifty percent of their students in the National FFA Organization. Interestingly the exact number of respondents that had less than fifty percent of their students having a SAE, also had less than fifty percent of their students in the National FFA Organization. These statistics show that in all programs the three parts of the agriculture education curriculum are not being taught or required of agriculture students.

When given specific professional agricultural organizations as examples and asked if they had or had not been involved with these, an overwhelming majority of the respondents, seventy-five percent or more in each category had not been a member of a professional organization. With a majority of respondents being in the later stages of their teaching career this is an alarming statistic. Professional agricultural organizations should be made more prevalent and their importance shown to teachers of all ages and experience levels in order to make the profession as successful as possible.

Although membership in professional agricultural organizations seemed low, membership in civic organizations looks more promising. Seventy-two percent of the respondents were involve in at least one civic organization. This could result from the local 
availability of the civic organizations. Professional agricultural organizations are on the regional, state, and national levels, and meet irregularly compared to the meetings of local civic organizations. Recognition is more prevalent from civic organizations in the community than professional agriculture organizations. Community members outside of the agricultural field may not understand the complexity of agriculture education profession, where the majority understands the purpose and effects of local civic organizations.

The instrument was divided into four main categories to determine what characteristics the current agricultural educators in West Virginia currently feel they possess. These categories were classroom instruction, organization structures and class management, professional responsibilities, and personal characteristics. Analysis of the individual areas have resulted in some areas that have varying results, and sparked the following thought process.

Agriculture instructors in the state of West Virginia responded to the instrument question that asked if they used written lesson plans. This is generally required in schools, so one would think that there should be an overwhelming response in the very often category. Although the very often area had fifty-seven percent of the respondents, there were two that rarely had written lesson plans, and six that sometimes had written lesson plans. This leads one to assume that in at least eight classrooms there are unplanned activities occurring. This isn't necessarily bad but one should think that all teachers should have lesson plans to ensure they are covering the material that is necessary and the content is always changing and invigorating to the students. This leads to another question asked of the respondents that stated they created their own lesson plans. Responses varied from the previous, resulting in sixty five percent of the respondents stating that they very often create their own lesson plans. There were no respondents in the never or rarely categories. This brings up a question that if lesson plans are created but not 
written, how are they evaluated? Why are administrators allowing teachers to be lax on the writing of lesson plans? All educators are trained to write lesson plans that incorporate all aspects of general education as well as their content area. Overwhelmingly the popular response when asked of the incorporation of reading, writing, and mathematics into the curriculum fell almost identically with approximately sixty percent of the respondents sometimes completing this in their classroom. This shows that agriculture educators are integrating their curriculum to allow students to understand how they will apply this in a future career. A majority of the respondents, approximately fifty-one percent, stated that they sometimes provided successful learning activities at each student's ability level, and that they challenged students to higher scholastic expectations. This shows that agriculture instructors have no problem challenging students, allowing them to apply their skills, while teaching them the importance of reading, writing, and mathematics.

Several interesting statistics come to the forefront in the category of questions in the organized structures and classroom management section. Agriculture instructors have several things occurring inside and outside of the classroom on a daily basis. They are expected to complete the paperwork and other requirements like regular education teachers. If the level of intensity continues at a high level, an up-to-date course of instruction would ensure that the program remains stable and on course to deliver the skills and information students need. Respondents to the survey were asked two questions regarding their course of instruction. For example, respondents were asked to rate how often their long range plans are based on an up to date course of instruction, and that the course of instruction has been approved by their advisory committee. Slightly above forty percent of the respondents very often completed both of these tasks. Twenty-four respondents sometimes made their long range plans on an up to date course 
of instruction, while seventeen respondents had their course of instruction sometimes approved by their advisory council. Combining the responses of both categories and both questions would lead one to see that a majority of agriculture instructors have a course of instruction that helps them guide long term instruction as well as it being approved by their advisory committee. The only disturbing response to the instrument was one respondent that never made long range plans based on a course of instruction.

Students are required to complete various assignments, tasks, prepare for college, and deal with all the stresses of teenage life. This leads to a question that is included in the class management section of the instrument. Exactly twenty-seven respondents in each category of sometimes and very often encouraged professional relationships with students. Seventy-one respondents very often encouraged respectful relationships with students. Students tend to look up to their agriculture teacher above other teachers due to the statistics from this instrument. Agriculture instructors take time to listen to students problems, and they visit students regularly while observing their SAE. This allows the agriculture instructor to understand the students personal situation more readily than other teachers who may only see them for ninety minutes a day.

Given the relationships with students as described previously agriculture teachers may be more likely to bypass a school rule in order to keep the professional, respectful relationship with their students. When asked how often they bypassed school policy when the situation warranted it, respondents overwhelmingly responded in the categories of sometimes, rarely, and never. These three categories consumed ninety-two percent of the responses. Only one respondent very often bypassed school policy when the conditions warranted it. It depends on the situation an instructor is put into and the split second decision that has to be made, whether a instructor 
bypasses policy or enforces it strictly. Twenty-three percent of the respondents reported that they never bypass school policy. This is encouraging but must increase if agriculture teachers are to maintain relationships with students on a professional and respectful level.

Fifty nine percent of respondents very often recognized their students for their efforts. Thirty-nine percent of respondents frequently recognized their students for their efforts. This again adds to the respectful and professional relationships with students. If recognized for their efforts students will be more likely to perform for the person recognizing them for their outstanding achievements. All respondents used humor and patients which promote positive interaction with their students, frequently or very often. Agriculture education is a hand's on curriculum in order to master the skills necessary to be successful in a career students have to be actively engaged in the curriculum. Agriculture educators through their personality, dedication, and respect for their students ensure that every student gets a quality well rounded education while they are in the agricultural classroom.

\section{Conclusions}

The following conclusions are based on interpretations of the data presented in this study. Respondents to this study were either in the early years of their teaching career (1-5 years) or towards the end of a long teaching career (26+ years). The age of respondents also was stretched to the extreme ends of the spectrum.

The number of agriculture instructors that were involved in professional agricultural organizations was small compared to the number of agricultural instructors involved in civic organizations. This would be a major area of improvement for the entire profession of agricultural and environmental educators. 
Very few respondents never or rarely performed tasks that would be considered risky in the high school classroom. On the category of classroom instruction, respondents were on the upper end of the scale and responded sometimes, frequently, or very often to the majority of the questions. Agricultural instructors created their own lesson plans, although they may not have been written they were created by the agricultural instructor instead of being used from an alternate source. Respondents to the instrument challenged students to higher academic standards and encouraged the incorporation of mathematics, reading, and writing into the curriculum. Agricultural instructors were willing to accept feedback from students about the content or organization of the classroom instruction. They had no problems with explaining assignments to students a second time or more if they didn't understand the material.

The second groups of questions were based on organized structures and class management. This section related to the course of instruction and how the classroom is organized and managed on a daily and long term basis. A majority of the respondents had a course of instruction that helped guide the classroom instruction in the long term, and it was approved by the advisory committee. This allows the conclusion to be drawn that agricultural programs that are to be considered successful need to have a guiding force that helps them to continue the excellence and a course of instruction that is approved by the advisory committee is the main instrument for doing this.

Very often the rules were established to manage student behavior in the agricultural classroom. Students were encouraged frequently to give input into the organization and creation of the classroom. Classrooms were rearranged several times during the year to keep interest in the subject matter. This allows for students to observe the class from different perspectives throughout the year, and through differing assignments. The information presented on the 
blackboard is almost always read easily by the students and students are recognized for their efforts which are worthy of praise.

Under the category of professional responsibilities, agricultural instructors frequently completed tasks assigned to them in a timely manner; they also keep abreast of new developments in their profession frequently. Agricultural instructors are overwhelmingly involved in their professional responsibilities, but as always there are exceptions to the rule and some instructors do not excel in this area.

Personal characteristics were the final category on the instrument. All agricultural instructors felt that they displayed personality traits such as humor and patience. This is very important in the agricultural education profession, because problems are always coming up and things do not always work out as they are planned. Agricultural instructors respond to changing situations within the classroom environment frequently. This along with a sense of humor and patience makes the agricultural classroom a professional, respectful environment even the nontraditional student can enjoy. Agricultural instructors are enthusiastic towards their work and feel capable of handling any challenge associated with their work. Agricultural instructors are very flexible professionals that make the classroom environment an enjoyable experience for all that enter it. An enthusiasm for their work makes students want to be in the classroom and learn the principles that are being taught. Agricultural instructors are a rare breed of teacher that can adapt to any situation and keep students interested no matter the circumstances.

\section{Recommendations}

The following recommendations are based on the results of this study to determine an effective evaluation method for agricultural instructors, based on the characteristics they feel they possess at the current point in their teaching career. 
1. It is recommended that agricultural educators get more involved in professional agricultural organizations so that they can be aware of the changing circumstances that directly affect them.

2. It is recommended that a method of evaluation be developed that incorporates all three aspects of the agricultural education curriculum.

3. It is recommended that evaluation of agricultural instructors be based on the characteristics studied herein.

4. It is recommended that regular evaluation of agricultural instructors inside and outside of the classroom be conducted and results be evaluated so that areas of improvement can be presented to agricultural educators at the post secondary level.

5. It is recommended that replications of this study be done with a larger population by increasing the scope of teachers included to find areas of improvement needed based on the characteristics studied in this instrument.

6. It is recommended that studies using the same population as the one in this study look more at specific characteristics that showed varying results among the respondents, to see why they are responding the way they are. 


\section{REFERENCES}

Hillison, J. (1998). The Role of the agricultural education teacher educator yesterday, today, and tomorrow. Journal of Agriculture Education, 39(1) 1-7.

Hughes, M., \& Barrick, R. K. (1993). A model for agricultural education in public schools. Journal of Agriculture Education, 59-67.

Miller, W.W., Kahler, A.A., \& Rheault, K. (1989). Profile of the effective vocational agriculture teacher. Journal of Agriculture Education, 30(2) 33-40.

National FFA Organization. (2000). Agriculture teacher's manual. Washington, DC: Author.

Phipps, L. J., \& Osborne, E. W. (1988). Handbook on agriculture education in public schools ( $2^{\text {nd }}$ ed.) Danville, IL: The Interstate.

Roberts, T. G., \& Dyer, J. E. (2002). Characteristics of effective agriculture teachers. Agriculture Education Magazine.

Rollins, T. J., \& Scanlon, D. C. (1991). The cognitive, perceptual, and instructional preferences of agricultural education students. Journal of Agricultural Education 48-54 
APPENDICES 
APPENDIX A

Cover Letter 
February 11, 2004

«ATFirst_Name» «ATLast_Name»

«School_Name»

«Address»

«City», «State» «Zip»

Dear «Sal»,

I am in the process of conducting a research study to determine the profile of the effective agricultural education teacher. The results will be useful to WVU's Agricultural Education Department in the preparation of agricultural educators and the State Agriculture Education staff in providing valuable inservice opportunities.

The purpose of this study is to determine the characteristics of an effective agricultural education teacher. The results of the study will be used to prepare a thesis to partially fulfill the requirements for a Master of Science Degree in Agricultural Education. By determining the characteristics of an effective teacher, the preservice and inservice can be modified to better service prospective teachers, as well as teachers currently employed in the state.

On the enclosed questionnaire, you will be asked to identify how often you incorporate various activities and characteristics into your daily classes and for additional demographic data. Participation in this research study, while voluntary, will only take a few minutes of your time. You may skip any question you are not comfortable answering. Please be assured that all information will be held as confidential as possible. Survey results will be reported in a summary format and individual responses will not be identifiable. You will notice a code number at the top right of the first page of the survey. This code will be used to identify nonrespondents for follow-up and will be destroyed before the data are analyzed. A postage-paid self-addressed return envelope is provided for your convenience.

Participation in the research by returning the questionnaire before February 27, 2004 will be greatly appreciated.

Sincerely,

James C. Beatty

Graduate Student
Harry N. Boone

Assistant Professor 
APPENDIX B

Follow-Up Cover Letter 
March 3, 2004

«ATFirst_Name» «ATLast_Name»

«School_Name»

«Address»

«City», «State» «Zip»

Dear «Sal»,

You recently received a questionnaire regarding the characteristics of an effective agricultural education teacher. As of today, I have not received your response. Your response is crucial to the success of this research project, therefore, I am contacting you a second time with the hopes that you will participate in the project by completing and returning the questionnaire.

I am conducting a research study to determine the profile of the effective agricultural education teacher. The results will be useful to WVU's Agricultural Education Department in the preparation of agricultural educators and the State Agriculture Education staff in providing valuable inservice opportunities.

The purpose of this study is to determine the characteristics of an effective agricultural education teacher. The results of the study will be used to prepare a thesis to partially fulfill the requirements for a Master of Science Degree in Agricultural Education. By determining the characteristics of an effective teacher, the preservice and inservice can be modified to better service prospective teachers, as well as teachers currently employed in the state.

On the enclosed questionnaire, you will be asked to identify how often you incorporate various activities and characteristics into your daily classes and for additional demographic data. Participation in this research study, while voluntary, will only take a few minutes of your time. You may skip any question you are not comfortable answering. Please be assured that all information will be held as confidential as possible. Survey results will be reported in a summary format and individual responses will not be identifiable. You will notice a code number at the top right of the first page of the survey. This code will be used to identify non-respondents for follow-up and will be destroyed before the data are analyzed. A postage-paid self-addressed return envelope is provided for your convenience.

\section{Participation in the research by returning the questionnaire before March 15, 2004 will be greatly appreciated.}

Sincerely,

James C. Beatty

Graduate Student
Harry N. Boone

Assistant Professor 
APPENDIX C

Questionnaire 


\section{Characteristics of an Effective Agriculture Educator}

Instructions: Using a Likert scale ranging from 1 to 5 , please indicate the frequency you perform each of the following tasks. Indicate your agreement by circling the number that best corresponds to your response. Use the following scale: $1=$ Never, $2=$ Rarely, $3=$ Sometimes, 4 = Frequently, 5 = Very Often.

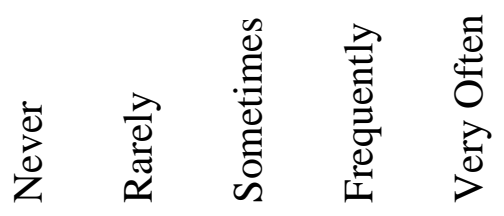

\section{Classroom Instruction}

1. I develop course activities that reflect lifelike situations

2. I relate current lessons to past lessons

$\begin{array}{lllll}1 & 2 & 3 & 4 & 5 \\ 1 & 2 & 3 & 4 & 5\end{array}$

3. I use learning activities which are designed to achieve predetermined objectives for the lesson/unit

4. I have written lesson plans.

5. I create my own lesson plans.

$\begin{array}{lllll}1 & 2 & 3 & 4 & 5 \\ 1 & 2 & 3 & 4 & 5 \\ 1 & 2 & 3 & 4 & 5\end{array}$

6. I provide successful learning activities at each student's ability level.

7. I challenge students to higher scholastic expectations

$\begin{array}{lllll}1 & 2 & 3 & 4 & 5 \\ 1 & 2 & 3 & 4 & 5\end{array}$

8. I use motivation (interest approach) to create a felt need on why the students should study the topic.

9. I accept honest feedback from students.

$\begin{array}{lllll}1 & 2 & 3 & 4 & 5 \\ 1 & 2 & 3 & 4 & 5\end{array}$

10. I provide written comments on exams to facilitate student learning

$\begin{array}{lllll}1 & 2 & 3 & 4 & 5\end{array}$

11. I further explain assignments to students even after directions are given.

$\begin{array}{lllll}1 & 2 & 3 & 4 & 5\end{array}$

12. I design educational activities for the class as a whole rather than for individual students

13. I seek the advice of experts in the subject matter

$\begin{array}{lllll}1 & 2 & 3 & 4 & 5 \\ 1 & 2 & 3 & 4 & 5\end{array}$

14. I use a pre-organizer to help direct student thinking when they enter the classroom.

$\begin{array}{lllll}1 & 2 & 3 & 4 & 5\end{array}$

15. I help students locate supplementary materials to the subject matter content covered in class.

16. I promote reading skill development in my classes.

17. I promote writing skill development in my classes.

$\begin{array}{lllll}1 & 2 & 3 & 4 & 5 \\ 1 & 2 & 3 & 4 & 5 \\ 1 & 2 & 3 & 4 & 5\end{array}$


18. I promote math skill development in my classes.

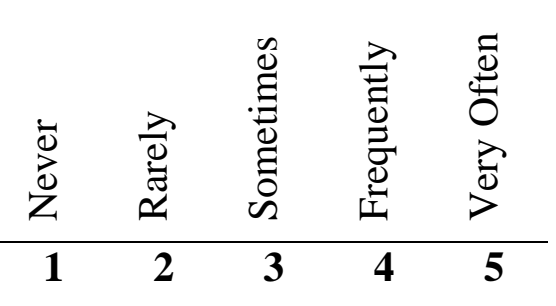

\section{Organized, Structures, and Class Management}

19. I utilize long range plans to guide improvement of the agricultural education program

$\begin{array}{lllll}1 & 2 & 3 & 4 & 5\end{array}$

20. My long range plans are based on an up-to-date course of instruction.

$\begin{array}{lllll}1 & 2 & 3 & 4 & 5\end{array}$

21. My course of instruction is approved by my advisory committee.

$\begin{array}{lllll}1 & 2 & 3 & 4 & 5\end{array}$

22. I establish a given set of rules and procedures to manage student behavior.

$\begin{array}{lllll}1 & 2 & 3 & 4 & 5\end{array}$

23. I allow for student input when establishing classroom rules and procedures.

24. I purposely adjust and rearrange the classroom to provide for a variety of learning activities within the classroom.

25. I confront students when they are not on the assigned task.

26. I present information on the blackboard/whiteboard which can be read by all students.

27. I use textbooks to provide most of the printed information given to students.

$\begin{array}{lllll}1 & 2 & 3 & 4 & 5\end{array}$

$\begin{array}{lllll}1 & 2 & 3 & 4 & 5\end{array}$

$\begin{array}{lllll}1 & 2 & 3 & 4 & 5\end{array}$

$\begin{array}{lllll}1 & 2 & 3 & 4 & 5\end{array}$

$\begin{array}{lllll}1 & 2 & 3 & 4 & 5\end{array}$

28. I encourage professionally friendly relationships with students.

29. I encourage respectful relationships with students.

30. I use sarcasm in the classroom

31. I constructively criticize students for further educational improvement.

32. I keep informed about students needing special assistance

33. I willingly provide time for any student needing extra help.

34. I involve parents of students in program related activities.

35. I share teaching ideas and methods with other teachers in the school.

$\begin{array}{lllll}1 & 2 & 3 & 4 & 5 \\ 1 & 2 & 3 & 4 & 5 \\ 1 & 2 & 3 & 4 & 5\end{array}$

$\begin{array}{lllll}1 & 2 & 3 & 4 & 5\end{array}$

$\begin{array}{lllll}1 & 2 & 3 & 4 & 5\end{array}$

$\begin{array}{lllll}1 & 2 & 3 & 4 & 5\end{array}$

$\begin{array}{lllll}1 & 2 & 3 & 4 & 5\end{array}$

$\begin{array}{lllll}1 & 2 & 3 & 4 & 5\end{array}$

36. I categorize students by their needs (cultural, academic, intellectual, etc.)

$\begin{array}{lllll}1 & 2 & 3 & 4 & 5\end{array}$ 


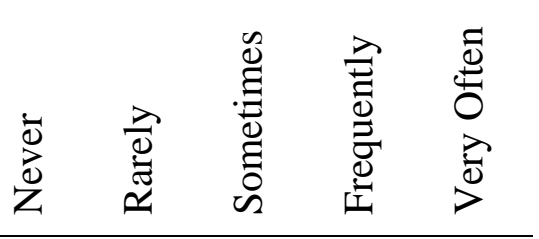

37. I recognize students for their efforts which are worthy of praise.

\section{Professional Responsibilities}

38. I complete duties in a timely manner.

39. I keep abreast of new developments within my profession

40. I participate in workshops, field days, and seminars.

41. I bypass school policy when the conditions warrant it.

\section{Personal Characteristics}

$\begin{array}{lllll}1 & 2 & 3 & 4 & 5\end{array}$

42. I display personality traits such as humor and patience which promote positive interaction with students.

43. I feel enthusiastic toward my work.

$\begin{array}{lllll}1 & 2 & 3 & 4 & 5\end{array}$

$\begin{array}{lllll}1 & 2 & 3 & 4 & 5\end{array}$

$\begin{array}{lllll}1 & 2 & 3 & 4 & 5\end{array}$

$\begin{array}{lllll}1 & 2 & 3 & 4 & 5\end{array}$

$\begin{array}{lllll}1 & 2 & 3 & 4 & 5\end{array}$

$\begin{array}{lllll}1 & 2 & 3 & 4 & 5\end{array}$

44. I feel capable of handling any of the challenges associated with my work.

$\begin{array}{lllll}1 & 2 & 3 & 4 & 5\end{array}$

45. I cope easily with the changing situations occurring within the classroom environment.

$\begin{array}{lllll}1 & 2 & 3 & 4 & 5 \\ 1 & 2 & 3 & 4 & 5\end{array}$

$\begin{array}{lllll}1 & 2 & 3 & 4 & 5\end{array}$

\section{Demographic Information}

46. In what age category are you?

$\begin{array}{cl}\text { a. } & 21-25 \text { years } \\ \text { b. } & 26-30 \text { years } \\ \text { c. } & 31-35 \text { years } \\ \text { d. } & 36-40 \text { years } \\ \text { e. } & 41-50 \text { years } \\ \text { f. } & 51-60 \text { years } \\ \text { g. } & 61 \text { years or more }\end{array}$


47. Using the following categories, indicate the number of years of teaching experience you have.
a. $1-5$ years
b. $6-10$ years
c. $11-15$ years
d. $\quad 16-20$ years
e. $\quad 21-25$ years
f. 26 years or more

48. How many years have you lived on a farm?

$\begin{aligned} \text { a. } & \text { I have never lived on a farm } \\ \text { b. } & 1-5 \text { years } \\ \text { c. } & 6-10 \text { years } \\ \text { d. } & 11-15 \text { years } \\ \text { e. } & 16-20 \text { years } \\ \text { f. } & 21-25 \text { years } \\ \text { g. } & 26 \text { years or more }\end{aligned}$

49. How many years have you lived in your current school district?

$\begin{aligned} \text { a. } & \text { Less than } 1 \text { year } \\ \text { b. } & 1-5 \text { years } \\ \text { c. } & 6-10 \text { years } \\ \text { d. } & 11-15 \text { years } \\ \text { e. } & 16-20 \text { years } \\ \text { f. } & 21-25 \text { years } \\ \text { g. } & 26 \text { years or more }\end{aligned}$

50. What percent of your students have an active Supervised Agriculture Experience Program?

a. $0-25 \%$

b. $26-50 \%$

c. $51-60 \%$

d. $\quad 61-70 \%$

e. $\quad 71-80 \%$

f. $\quad 81-90 \%$

g. $91-100$ 
51. What percent of your students are FFA members?

\begin{tabular}{rr} 
a. & $0-25 \%$ \\
b. & $26-50 \%$ \\
c. & $51-60 \%$ \\
d. & $61-70 \%$ \\
\hline e. & $71-80 \%$ \\
f. & $81-90 \%$ \\
g. & $91-100$
\end{tabular}

50. How many professional agriculture organizations are you a member? (Please list)

51. How many civic organizations are you a member?

52. How many leadership positions have you held in professional teacher organizations?

53. How many leadership positions have you held in professional agriculture organizations?

54. How many leadership positions have you held in civic organizations?

55. How many professional development workshops have you participated in during the past two years? 


\section{VITA}

Born:

Graduated High School:

Associate Degree:

Bachelors Degree:

Master’s Degree:

Student Teaching :

Teaching Experience:

Leadership Positions:

\section{Program Improvement:}

May 6, 1979

Keyser High School

June 1997. GPA: 3.5

Agricultural and Environmental Education

Potomac State College, May 1999. GPA: 3.5

Agricultural and Environmental Education

West Virginia University, May 2001. GPA: 3.49

Agricultural and Environmental Education

West Virginia University, December 2004. GPA: 3.6

Hampshire High School, Supervised by Mr. Paul Roomsburg, Ronnie Watson, and Bill Chaney. Spring 2001

Experience in: Horticulture, Forestry, Ag Mechanics, and General Agriculture.

Substitute Teacher: Hampshire County May 2001-June 2001 Experience: Middle and High School academic and vocational classrooms.

Elkins High School, July 2001-present.

Current course offerings: Agriculture and Natural Resources 1 and 2, Agriscience 11 and 12, Forestry 1 and 2, Animal and Veterinary Science Small Animals, Animal and Veterinary Science Large Animals.

Average Student Enrollment per Year: 100

FFA Membership: 60\%

SAE Programs: 50\%

Hosted WVU Summer Course 2002

Faculty Senate President, 2002-2003

Core Content Test Creation, Summer 2003

Eastern Region Agriculture Teachers, President 2003-2004

Curriculum Committee Elkins High School: 2001-present

$\$ 115,000.00$ over 4 years to improve program by:

New 30’ X 60’ Greenhouse

1000 gallon Aquaculture Recirculation System

Hydroponics Tables

Shop Equipment and Tool Modernization

Forestry Equipment, Chainsaw, Chaps, Tools 